\title{
The Mozambique Ridge: a document of massive multistage magmatism
}

\author{
Maximilian D. Fischer, ${ }^{1}$ Gabriele Uenzelmann-Neben, ${ }^{1}$ Guillaume Jacques ${ }^{2,3}$ \\ and Reinhard Werner ${ }^{2}$ \\ ${ }^{1}$ Alfred-Wegener-Institut Helmholtz-Zentrum für Polar- und Meeresforschung, Am Alten Hafen 26, D-27568 Bremerhaven, \\ Germany.E-mail: Maximilian.Fischer@awi.de \\ ${ }^{2}$ GEOMAR Helmholtz-Zentrum für Ozeanforschung, Wischhofstr. 1-3, D-24148 Kiel, Germany \\ ${ }^{3}$ Bundesanstalt für Geowissenschaften und Rohstoffe, Stilleweg 2, D-30655 Hannover, Germany
}

Accepted 2016 October 25. Received 2016 October 11; in original form 2016 July 29

\begin{abstract}
SUMMAR Y
The Mozambique Ridge, a prominent basement high in the southwestern Indian Ocean, consists of four major geomorphological segments associated with numerous phases of volcanic activity in the Lower Cretaceous. The nature and origin of the Mozambique Ridge have been intensely debated with one hypothesis suggesting a Large Igneous Province origin. High-resolution seismic reflection data reveal a large number of extrusion centres with a random distribution throughout the southern Mozambique Ridge and the nearby Transkei Rise. Intrabasement reflections emerge from the extrusion centres and are interpreted to represent massive lava flow sequences. Such lava flow sequences are characteristic of eruptions leading to the formation of continental and oceanic flood basalt provinces, hence supporting a Large Igneous Province origin of the Mozambique Ridge. We observe evidence for widespread post-sedimentary magmatic activity that we correlate with a southward propagation of the East African Rift System. Based on our volumetric analysis of the southern Mozambique Ridge we infer a rapid sequential emplacement between $\sim 131$ and $\sim 125 \mathrm{Ma}$, which is similar to the short formation periods of other Large Igneous Provinces like the Agulhas Plateau.
\end{abstract}

Key words: Submarine tectonics and volcanism; Large igneous provinces; Neotectonics; Africa; Indian Ocean.

\section{INTRODUCTION}

For several decades Large Igneous Provinces (LIPs) have been of great interest because of their immense sizes and potential farreaching impact on biosphere and atmosphere leading to climate shifts and mass extinctions (Wignall 2001), their role in plate motion by thickening of oceanic crust (Miura et al. 2004), and their association with continental breakup and supercontinent cycles (Bryan \& Ernst 2008; Bryan \& Ferrari 2013). The term LIP was initially proposed by Coffin \& Eldholm (1991) and is used for large $(>0.1 \times$ $10^{6} \mathrm{~km}^{2}$ ) marine and terrestrial areas overprinted by massive volcanic activity (Coffin \& Eldholm 1994; Bryan \& Ernst 2008; Kerr 2014). Episodes of excessive magmatism have repeatedly formed LIPs on Earth by eruptions from a system of fissures or vents (Uenzelmann-Neben 2013). Three proposed models to explain these massive outpourings of magma are the impact of a rising plume head at the base of the lithosphere, edge-driven convection, or lithospheric delamination (Coffin \& Eldholm 1994; White \& McKenzie 1995; Saunders 2005; Campbell 2007). In Cretaceous times, an increase in development of LIPs occurred globally, for example, Manihiki Plateau in the Pacific Ocean and Rio Grande Rise in the Atlantic Ocean (Coffin \& Eldholm 1994). In the Indian
Ocean emplacement of several structures such as the Kerguelen Plateau (Frey et al. 2000) and the Agulhas Plateau (Parsiegla et al. 2008) are associated with massive volcanic events and classified as LIPs.

The Mozambique Ridge (MozR) is located in the southwestern Indian Ocean (Fig. 1), an area where Gondwana breakup between Africa, South America and Antarctica occurred during the Cretaceous. The areal extent $\left(\sim 2 \times 10^{5} \mathrm{~km}^{2}\right)$ of the elongated aseismic ridge is nearly twice the size of Iceland. The MozR is limited to the east by an abrupt, more than $2000 \mathrm{~m}$ deep step-down into the Mozambique Basin (dashed line in Fig. 1), which owes its existence to the NNE-SSW striking Andrew Bain fracture zone (BenAvraham et al. 1995; Sclater et al. 2005). To the north, the MozR is bound by the Northern Natal Valley, to the west by the Southern Natal Valley and to the south by the Transkei Basin and Transkei Rise (Fig. 1). Geomorphologically it is divided into four segments, termed here as northern MozR (nMozR), central MozR (cMozR), southwestern MozR (swMozR) and southeastern MozR (seMozR). Together the latter three form the southern MozR (Fig. 1). The first samples from the basement of the MozR were collected at DSDP Leg 25 Site 249 on the $\mathrm{nMozR}$, where $3.1 \mathrm{~m}$ of tholeiitic basalt was recovered (Simpson et al. 1974). 


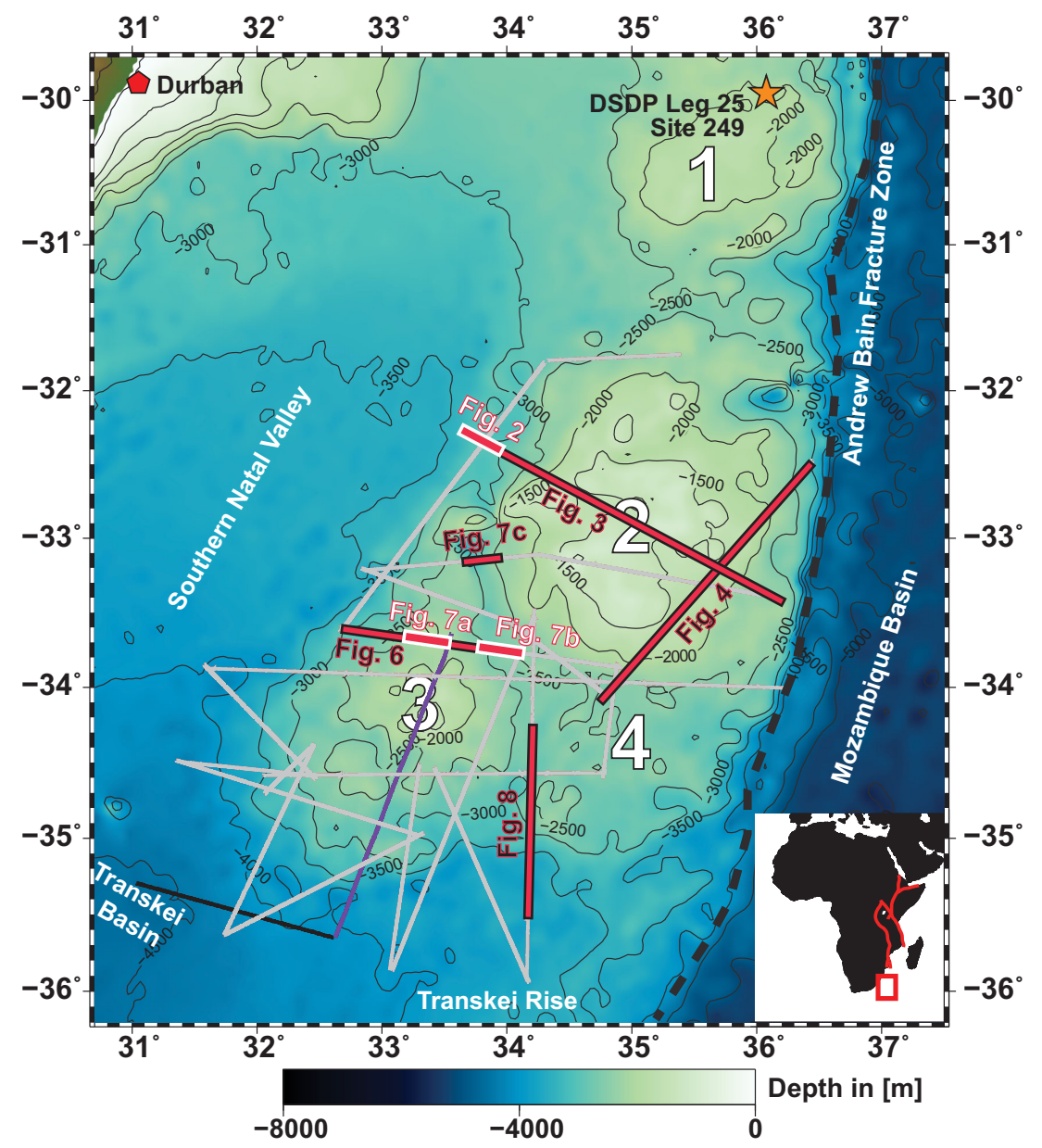

Figure 1. Bathymetric map (GEBCO_08; $500 \mathrm{~m}$ contour lines in black) of the study area in the southwestern Indian Ocean with location of DSDP Leg 25 Site 249 (star) and Durban, South Africa (pentagon). MCS profiles of SO 232 are shown in grey, those of SO 182 in black and purple. Seismic refraction profile interpreted by Gohl et al. (2011) is coincident with NNE-SSW striking MCS profile AWI-20050018 of SO 182 depicted in purple (Gohl et al. 2011 ; Uenzelmann-Neben et al. 2011). White numbers depict the segments of the Mozambique Ridge: $1=$ northern Mozambique Ridge, $2=$ central Mozambique Ridge, 3 = southwestern Mozambique Ridge, 4 = southeastern Mozambique Ridge. Red bars (black outline) indicate the locations and lateral extent of presented seismic data. White outlines are used if the respective figures represent an extract of shown seismic data. The insert shows the location of the study area off South Africa (red rectangle) and the major rift features of the East African Rift System (after Tikku et al. 2002; Chorowicz 2005; Macgregor 2015).

Authors have proposed several hypotheses about the nature and origin of the MozR, ranging from a continental provenance (Tucholke et al. 1981; Raillard 1990; Mougenot et al. 1991; Hartnady et al. 1992), to an oceanic origin (Hales \& Nation 1973; König \& Jokat 2010), to being partitioned into continental and oceanic parts (Ben-Avraham et al. 1995). Seismic refraction and reflection data collected across the swMozR are interpreted as strong evidence for an oceanic LIP origin of the southern MozR (parallel to the purple line in Fig. 1; Gohl et al. 2011). A LIP origin of the whole MozR could have had an immense influence on climate during the Early Cretaceous with the emission of gases and heat into atmosphere and ocean and in addition implications on the development of the South African gateway with the formation of obstacles for surface and deep circulation.

The main objective of this paper is to resolve the structure and evolution of the MozR by focusing on the questions of formation and magmatism using seismic reflection data. This will provide parameters required for future studies about the reconstruction of the paleo-ocean current circulation and its implications for climate.

\section{GEOLOGICAL AND TECTONIC BACKGROUND}

The origin of the MozR is still unclear. In general, three totally different theories have been proposed to explain its development history. Tucholke et al. (1981) suggested a continental provenance of the MozR based on a comparison of 1-D seismic refraction data from Hales \& Nation (1973) and Chetty \& Green (1977) with seismic refraction data from the Agulhas Plateau that was interpreted to be a continental fragment of South Africa. Dredge samples presented by Raillard (1990), Mougenot et al. (1991), and Hartnady et al. (1992) supported a continental origin of the MozR. BenAvraham et al. (1995) favoured a partitioning of the MozR into a northern oceanic and a southern continental part. They suggested a microcontinental fragment embedded into oceanic crust at the southern MozR based on low-resolution seismic refraction data of Hales \& Nation (1973) and Raillard (1990), gravity data (Doucouré \& Bergh 1992; Lyakhovsky et al. 1994), and rock samples (Raillard 1990; Mougenot et al. 1991; Hartnady et al. 1992; Ben-Avraham et al. 1995). 
Based on the interpretation of gravity anomaly data and a recent magnetic survey, König \& Jokat (2010) contradicted this model by excluding the presence of large continental blocks throughout the MozR. According to their observations, high amplitude magnetic anomalies at the major structural boundaries suggest that the different segments of the ridge were formed at different times. They described the MozR as the result of long lasting volcanic activity between $140 \mathrm{Ma}$ (magnetic anomaly $\sim \mathrm{M} 15 \mathrm{n}$ ) and $122 \mathrm{Ma}$ (magnetic anomaly C34n, onset of Cretaceous Normal Superchron) and proposed an oceanic origin for the whole ridge. The findings of Erlank \& Reid (1974), Simpson et al. (1974), and Thompson et al. (1982), who dated the basaltic basement at Site 249 (location see Fig. 1) as Early Cretaceous, support the postulated timeframe of emplacement. A more than $22 \mathrm{~km}$ thick crust was identified for the MozR during a 1-D seismic refraction study (Hales \& Nation 1973; Chetty \& Green 1977). Chetty \& Green (1977) concluded that the over-thickened crust lacks characteristic velocities of the continental basement and therefore a basement of continental crust was not strongly supported. The interpretation of 2-D seismic refraction data showed that the MozR is characterized by over-thickened (16-22 km), seismically homogeneous, lower crustal units making up between half to two-thirds of the crustal column with $P$-wave velocities of more than $7.0 \mathrm{~km} \mathrm{~s}^{-1}$ (Gohl et al. 2011). According to them these velocities suggest that large volumes of mantle-derived material accreted in the lower crust and indicate a formation of MozR and Agulhas Plateau at the same magmatic province (Gohl \& Uenzelmann-Neben 2001; Parsiegla et al. 2008). As a consequence of their studies Gohl et al. (2011) proposed a LIP origin of the MozR and speculated on the existence of a Southeast African LIP consisting of the MozR, the Agulhas Plateau and other fragments. Preliminary petrological-geochemical results of the basaltic rock samples dredged during SO 232 favour a deep-plume source and support a LIP origin of the MozR (Uenzelmann-Neben 2014; Jacques et al. 2015).

\section{DATA AND METHODS}

\subsection{Seismic reflection data}

This study is based on 24 high-resolution MCS reflection profiles with a total length of about $4600 \mathrm{~km}$ acquired by the Alfred Wegener Institute, Helmholtz Centre for Polar and Marine Research on board RV Sonne during expeditions SO 182 in 2005 (black and purple lines in Fig. 1) and SO 232 in 2014 (grey lines in Fig. 1). The seismic profiles cover the cMozR, the swMozR, and the seMozR of the MozR, as well as the transition zone to the adjacent basins (Fig. 1). A cluster of four GI-guns were triggered at a nominal interval of $25 \mathrm{~m}$ (shot interval of $10 \mathrm{~s}$ ), generating seismic signals of up to $500 \mathrm{~Hz}$ with dominant frequencies between 20 and $55 \mathrm{~Hz}$. Each GI-gun produces a primary pulse (Generator) with a volume of 0.72 litres, which is followed by a delayed $(33 \mathrm{~ms})$ secondary signal (Injector volume 1.681 ) to suppress the bubble effect. The data were received by a 240 -channel hydrophone array with a total active length of $3000 \mathrm{~m}$. Navigation data were specified by GPS.

Pre-stack processing of the multichannel seismic data included geometry definition using the ship's navigation data, and common depth point (CDP) sorting with a CDP spacing of $25 \mathrm{~m}$. A detailed velocity analysis (every $50 \mathrm{CDP}$ ) was carried out and used for normal moveout correction. Where needed, the interval for the velocity analysis was decreased (e.g. for complex, small scale features). Stacking was carried out using a mean iterative algorithm together with spherical divergence correction and was followed by an Omega-X finite-difference migration (Yilmaz 2001). This migration method is very useful for the imaging of strongly inclined reflectors as caused by, for example, volcanic structures or tectonic processes. Since seismic amplitude information was used for the interpretation we avoided AGC (Automatic Gain Control) filtering so that amplitudes depicted in the profiles represent values relative to the maximum of the entire section. For better visualization of the seismic data, band pass filtering with tapering (Hanning window; boundaries $5-30 \mathrm{~Hz}$ and $200-250 \mathrm{~Hz}$ ) and a water column mute were applied.

\subsection{DSDP data}

Site 249 was drilled during DSDP Leg 25 and recovered a thin segment of basaltic basement $(3.1 \mathrm{~m})$ from a depth of 408 meters below seafloor (mbsf). Due to severe weathering of the rock samples no radiometric age dating was possible, but major and trace element analysis showed compositional similarities with mid-ocean ridge tholeiites (Erlank \& Reid 1974). Based on the age of the overlying sediments, Simpson et al. (1974) inferred an Early Neocomian age of the tholeiitic basalt. Three lithological units were identified by means of lithological and biostratigraphic characteristics (Simpson et al. 1974). Those units are separated by two prominent hiatuses: a Campanian to Cenomanian unconformity (287 mbsf) representing $\sim 25 \mathrm{Myr}$ and a Middle Miocene to Maastrichtian unconformity (172 mbsf) representing $\sim 50$ Myr. Sedimentation rates of $5 \mathrm{~m} \mathrm{Myr}^{-1}$ and $20 \mathrm{~m} \mathrm{Myr}^{-1}$ were determined for the Neocomian to Early Cenomanian and the Late Campanian to Maastrichtian, respectively, and a sedimentation rate of about $19 \mathrm{~m} \mathrm{Myr}^{-1}$ was calculated for the Miocene (Simpson et al. 1974). No direct correlation of the DSDP data to our seismic reflection data was possible since our profiles did not cross Site 249 located on the nMozR (Fig. 1). Nonetheless, the drilling results provide general information on the nature of unconformities observed in the sedimentary column and, in the absence of a more direct possibility of dating, thus were used to constrain our seismic stratigraphy.

\section{RESULTS}

\subsection{Seismic stratigraphy}

Three seismic units (basement, S1 and S2) were identified within the study area with the interfaces between the units representing distinct changes in seismic reflection characteristics (seismic stratigraphy; Vail et al. 1977; Cross \& Lessenger 1988). Based on their reflection characteristics (e.g. frequency, amplitude and continuity) the seismic units were correlated with the lithological results of DSDP Leg 25 Site 249 (Simpson et al. 1974) and the seismic units defined by Uenzelmann-Neben et al. (2011) to obtain a timeframe for their deposition. For the location of the MCS profile used by Uenzelmann-Neben et al. (2011) please refer to Fig. 1 (purple line crossing the swMozR). We present an overview of the seismic units and the correlations in Fig. 2 and Table 1.

\subsubsection{Basement}

The lowermost unit shows high amplitude, low frequency reflections (e.g. Fig. 2 CDPs 10200-10600). Intrabasement reflections can be deep reaching (e.g. up to $500 \mathrm{~ms}$ TWT in Fig. 2 CDPs 9000 9400). The intrabasement reflections are strongest and appear most 


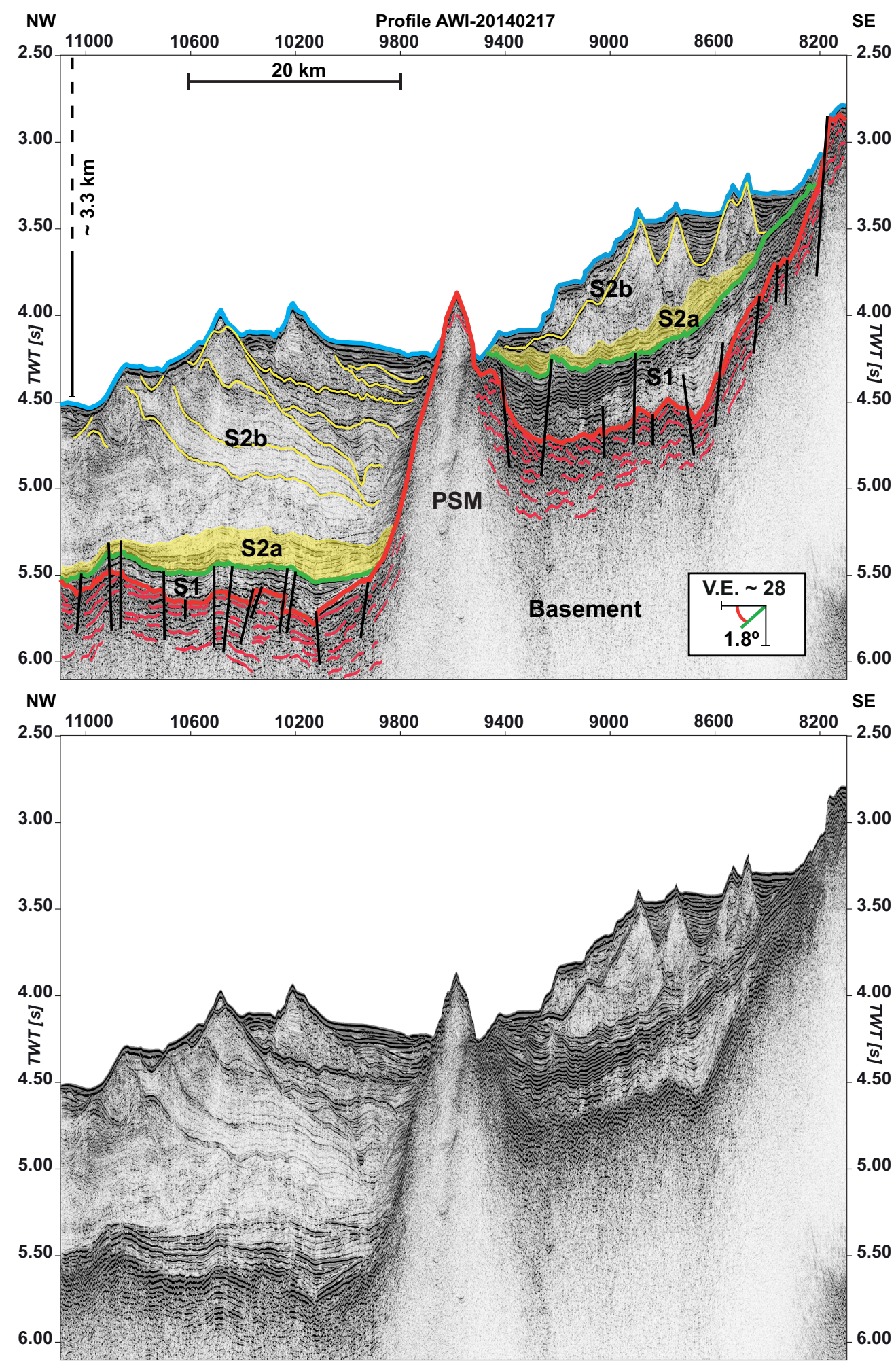

Figure 2. Seismic stratigraphy of the study area together with the uninterpreted section. Location of profile is shown in Fig. 1. For a detailed description of the units, refer to Section 4.1 and Table 1. Thick blue line = seafloor, thin yellow lines = discontinuities within subunit S2b, the yellow shaded area $=$ subunit S2a, thick green line $=$ top of unit S1, thick red line $=$ top of basement, thin red lines $=$ intrabasement reflections, black lines $=$ faults. PSM $=$ post-sedimentary magmatic structure. For slope angles and vertical exaggeration, refer to the legend.

continuous near the top of the unit and become increasingly weaker and less continuous with depth due to scattering and attenuation of the seismic signal. Individual reflections can typically be traced for $5-15 \mathrm{~km}$. The intrabasement reflections dip away from local highs and form subparallel sequences that in places overlap (e.g. Figs 3 CDPs 4000-4200 and 4 CDPs 1800-2200). The unit's top (red horizon in all shown MCS profiles) is defined by a strong impedance contrast with a sudden velocity increase to its overlying 


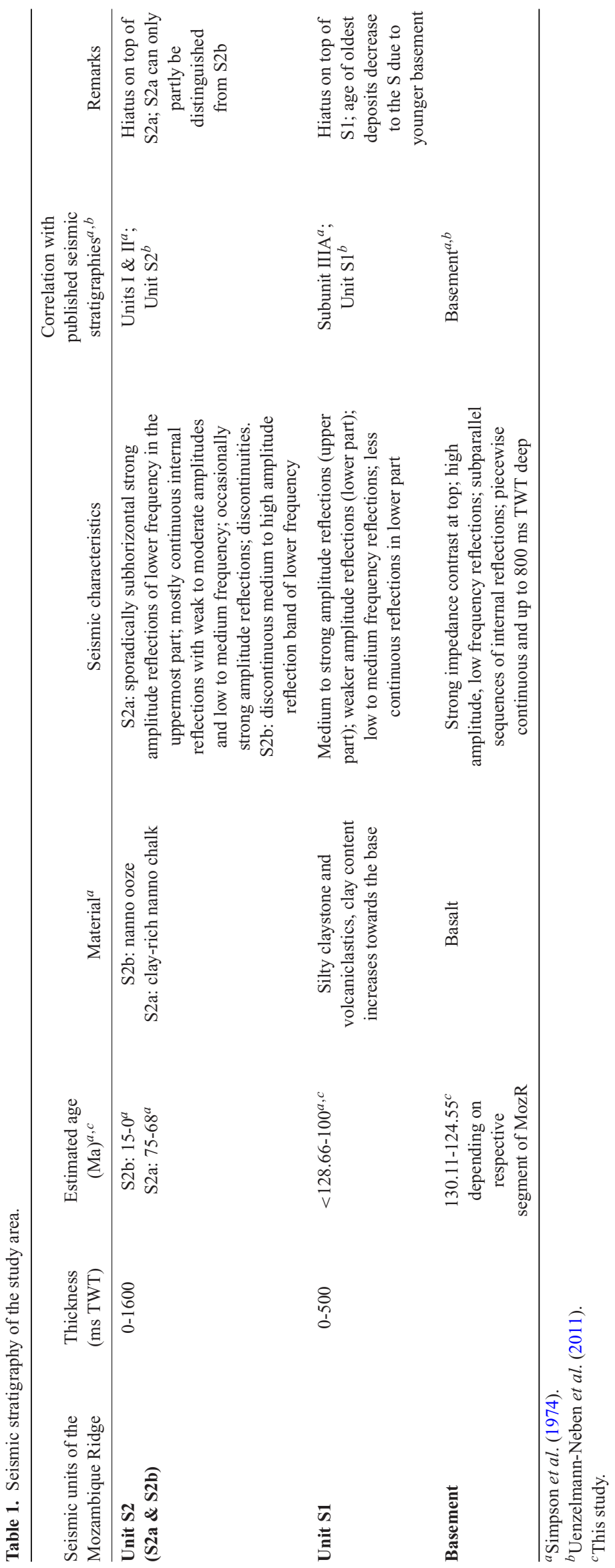


unit, appears rugged and hummocky, and shows a wide range in observed depths (Fig. 5a). Our observations match those described for the magmatic basement of the MozR by Simpson et al. (1974) and Uenzelmann-Neben et al. (2011), we thus interpret this unit as magmatic basement. Several faults disrupt the top basement reflection (e.g. Fig. 2 CDPs 10200-10600) and basement peaks piercing the sedimentary column appear locally (e.g. Fig. 2 CDPs 9300-9900).

\subsubsection{Seismic units $S 1$ and $S 2$}

Two seismic units (S1 and S2) overlie basement. Reflection characteristics of the well stratified older unit S1 show low to medium frequency reflections with weaker amplitudes in its lower part and medium to strong amplitude reflections in its upper part. The mostly conformable reflections of the unit are more continuous in the upper part (Fig. 2 CDPs 8400-9400). The top of unit S1 (green horizon in Fig. 2) seems to be affected by erosional truncation and is marked by a strong amplitude reflection. The unit has a thickness of up to $500 \mathrm{~ms}$ TWT and drapes the local morphology of the strongly faulted basement (Fig. 2 CDPs 8200-9500). Towards the surrounding basins (Natal Valley, Transkei Basin) and towards basement highs, unit S1 thins and in places is missing completely. The reflection characteristics of our unit S1 are similar to the reflection characteristics of lithological unit IIIA at Site 249 and to those of unit S1 described by Uenzelmann-Neben et al. (2011). Therefore, we correlate our seismic unit S1 with lithological unit IIIA of Site 249. The recovered deposits of unit IIIA at Site 249 consist of silty claystone and volcanic siltstone of Early Cretaceous (Neocomian to Early Cenomanian) age. The unit's top reflection (green horizon in Fig. 2) is described by Uenzelmann-Neben et al. (2011) as well and is correlated with the $\sim 25 \mathrm{Myr}$ hiatus (Early Cenomanian to Late Campanian) identified at Site 249 (Simpson et al. 1974).

With a thickness of up to $1600 \mathrm{~ms}$ TWT (e.g. Fig. 2 CDPs 10200), seismic unit S2 constitutes the largest part of the deposits covering the basement. The top of unit S2 is marked by the light blue horizon in Fig. 2. The unit typically thins towards basement highs (e.g. Fig. 2 CDPs 8200-9000) and can be divided into two subunits (S2a \& S2b) based on their reflection characteristics. In the lower part of unit S2 a thin (max. $250 \mathrm{~ms}$ TWT) discontinuous medium to high amplitude reflection band of lower frequency can be observed (Fig. 2 CDPs 8600-9400). The reflections onlap onto unit $\mathrm{S} 1$ and we observe a significant difference in reflection amplitude and frequency when comparing it to the more transparent nature of the overlying part of unit S2 (shaded in yellow in Fig. 2 CDPs 8500 9400 and 9800-11100). We define this reflection band as subunit S2a. Subunit S2a cannot be observed throughout the study area and usually thins towards basement highs. The thickest successions are observed within the surrounding basins of the MozR or within local depressions.

The Late Cretaceous (Late Campanian to Maastrichtian) lithological unit II drilled at Site 249 shows a variable thickness and thins towards the basement highs (Simpson et al. 1974). It is topped by a hiatus (Maastrichtian to Middle Miocene) as the result of erosion (Simpson et al. 1974). The seismic characteristics of lithological unit II resemble the characteristics of subunit S2a. Consequently, we correlate subunit S2a with the Late Campanian to Maastrichtian rocks drilled at Site 249. Uenzelmann-Neben et al. (2011) sporadically observed lower frequencies and stronger amplitude reflections in the lower $100 \mathrm{~m}$ of their seismic unit S2. Even though they could not correlate these reflections with certainty to the data of
Simpson et al. (1974), they interpreted this lower part to represent lithostratigraphic unit II.

The majority of seismic unit S2 consists of subunit S2b (thickness up to $1400 \mathrm{~ms}$ TWT), which shows a more transparent nature compared to the subjacent units (Fig. 2 CDPs 9800-11050). Its amplitudes are weak to moderate but occasionally strong and feature a low to medium frequency. We observe two groups of reflections characterized by significant differences in their seismic appearance in the uppermost part of unit S2b: a set of weak to moderate amplitude reflections of medium frequency, and a series of almost horizontal, well-layered strong amplitude reflections of lower frequency (e.g. Fig. 2 CDPs 8500-8800 and 10100-10600). The undulating, mostly continuous internal reflections of subunit $\mathrm{S} 2 \mathrm{~b}$ represent discontinuities (yellow lines in Fig. 2) such as erosional truncation and onlap termination (e.g. Fig. 2 CDPs 10000-10400).

We correlate the significant change in reflection characteristics between S2a and S2b to a distinct change in clay fraction content between lithological unit II (high clay fraction content of up to 60 per cent) and lithostratigraphic unit I (clay fraction content $<20$ per cent) (Leclaire 1974; Simpson et al. 1974). Uenzelmann-Neben et al. (2011) correlated the major part of their seismic unit S2 with lithostratigraphic unit I. We observe a similar thickness proportion of subunit S2b in relation to subunit S2a as Uenzelmann-Neben et al. (2011) described for the lower and upper parts of their seismic unit S2. We hence suggest that subunit S2b consists of the pelagic sediment of mid-Miocene to Holocene age of lithostratigraphic unit I recovered at Site 249 .

\subsection{Regional basement structure}

\subsubsection{Central Mozambique Ridge}

The basement at the cMozR has a rounded morphology (2 in Fig. 1) and gentle slopes that show a slight increase in dip to the NW and NE (Figs 3 and 4). A $\sim 15 \mathrm{~km}$ wide and $1600 \mathrm{~ms}$ TWT high basement peak on the NW flank disrupts the overall symmetry of the cMozR (Fig. 3 CDPs 9300-9900). The segment is built up of at least three basement complexes (BC1, BC2 and BC3, Figs 3, 4 and 5a). The shallowest area of the top basement reflection identified in seismic reflection data is located in the southern part of $\mathrm{BC} 1$ with a depth of 1590 ms TWT below sea level (bsl; south of BC1 in Fig. 3; black dashed ellipse in Figs $5 \mathrm{a}$ and b). In this part, the cMozR rises up to $3650 \mathrm{~ms}$ TWT above the basement in the Natal Valley. We observe only a thin sedimentary cover on top of basement highs (e.g. Figs 4 CDPs 3400-4200 and 5b). The individual basement complexes are separated by depressions (e.g. Fig. 4 CDPs 4800 6200). Faults associated with the depressions show offsets of up to $1500 \mathrm{~ms}$ TWT (Fig. 3 CDP 4800). The intrabasement reflections at the cMozR can be identified up to $800 \mathrm{~ms}$ TWT deep, and individual reflections are typically traced for $5-15 \mathrm{~km}$. Onlaps of intrabasement reflections onto other intrabasement reflections are observed, for example, between basement complex 2 and a $20 \mathrm{~km}$ wide basement high in the northeast of the cMozR (Fig. 4 CDPs 1800-2200).

\subsubsection{Southwestern Mozambique Ridge}

The basement at the swMozR (3 in Fig. 1) has gentle slopes and a rounded morphology that is slightly elongated to the $\mathrm{N}$ (Figs 5a and 6). The shallowest area of the top of the basement covered by seismic reflection data has a depth of $1920 \mathrm{~ms}$ TWT bsl (black dashed ellipse in Figs 5a and b; 'fig. 2 in Uenzelmann-Neben et al. 2011). 


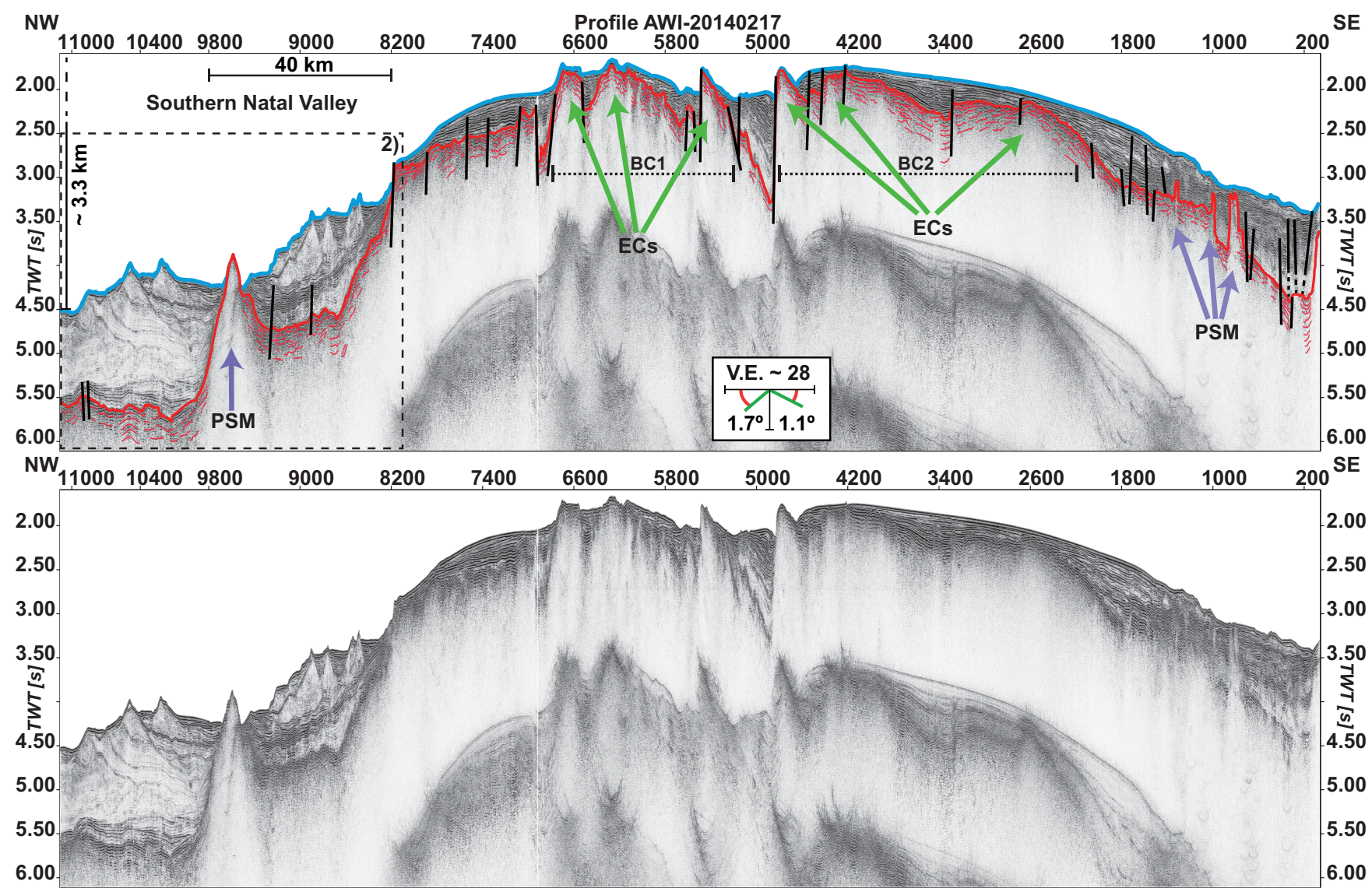

Figure 3. MCS profile AWI-20140217 crossing the central Mozambique Ridge in an NW-SE direction. Location of profile is shown in Fig. 1. Dashed frame indicates location of Fig. 2. Thick blue line $=$ seafloor, thick red line $=$ top of basement, thin red lines $=$ intrabasement reflections, black lines $=$ faults, green arrows $=$ extrusion centres $(\mathrm{ECs})$, purple arrows $=$ post-sedimentary magmatism $(\mathrm{PSM}) . \mathrm{BC} 1=$ Basement complex $1, \mathrm{BC} 2=\mathrm{Basement}$ complex 2. For slope angles and vertical exaggeration, refer to the legend.

We observe a thinning of the sedimentary cover towards basement highs (e.g. black dashed ellipse in Figs 5b and 6 CDPs 2800-2950). The swMozR is not as elevated as the cMozR, but still rises above the abyssal seafloor basement by up to $3500 \mathrm{~ms}$ TWT (Figs 5a and 6). The swMozR is separated from the cMozR by an NNW-SSE striking valley (Fig. 5a). The valley seems to have an asymmetrical shape as can be seen in Figs 6 (CDPs 4600-5000) and 7(c). We observe a greater abundance of faults and larger fault throws in the southern part of the swMozR with the result that the basement appears more fragmented than in the north. With a depth of up to $800 \mathrm{~ms}$ TWT below the top of basement the maximum depth of the observed intrabasement reflections is comparable to the cMozR (Fig. 6 CDPs 1300-1550 and CDPs 3000-3400). Within the valley between the cMozR and the swMozR intrabasement reflections emerging from local basement highs of the cMozR show onlap onto those emerging from local highs of the swMozR (Figs $7 b$ and c).

\subsubsection{Southeastern Mozambique Ridge}

In contrast to the cMozR and the swMozR, the seMozR (4 in Fig. 1) seems to have a smoother and more homogeneous basement topography, even though it is difficult to make a general statement based on the low data coverage of the seMozR. Seismic data suggest a rather uniform basement depth in east-west direction and a gentle dip of basement to the south (Figs $5 \mathrm{a}$ and 8 ). The depth ranges between $\sim 3500 \mathrm{~ms}$ TWT in the north and more than $4800 \mathrm{~ms}$ TWT in the south (Figs 5a and 8). Basement hence lies significantly deeper than on the other segments (Fig. 5a). Intrabasement reflections reach up to $600 \mathrm{~ms}$ TWT deep and follow the general southward dipping trend of top basement (Fig. 8 CDPs 4200-4600).

South of the seMozR we observe a smooth transition onto the Transkei Rise (Figs 1 and 8). The depth of top of basement is between 5500 and $6000 \mathrm{~ms}$ TWT bsl and thus lies about 1000 to $2000 \mathrm{~ms}$ TWT deeper than at the seMozR (Fig. 5a). Intrabasement reflections at the Transkei Rise show a maximum depth of $450 \mathrm{~ms}$ TWT below the top of basement.

\subsection{Magmatic structures}

The magmatic basement of the MozR and the Transkei Rise is characterized by prominent convex upward shaped structures (e.g. Fig. 3 CDPs 2400-2800, Fig. 4 CDPs 4200-4400), which form local highs. The structures are distributed randomly and do not seem to follow any apparent trend (Fig. 5c). The lateral extent of these structures can be up to $10 \mathrm{~km}$ (e.g. Fig. 3 CDPs 2400-2800, Fig. 6 CDPs 2700-3100 and Fig. 7a). Parallel (e.g. Fig. 3 CDPs 3400 4200) and subparallel (e.g. Fig. 6 CDPs 3200-4000) sequences of intrabasement reflections emerge, dip away and extend downhill from these local basement highs in opposing directions. Reflections at the summit are nearly horizontal and not as continuous as those on the flanks, and we observe nearly no intrabasement reflections beneath the summits (e.g. Fig. 3 CDPs 2400-2800). Our observations 


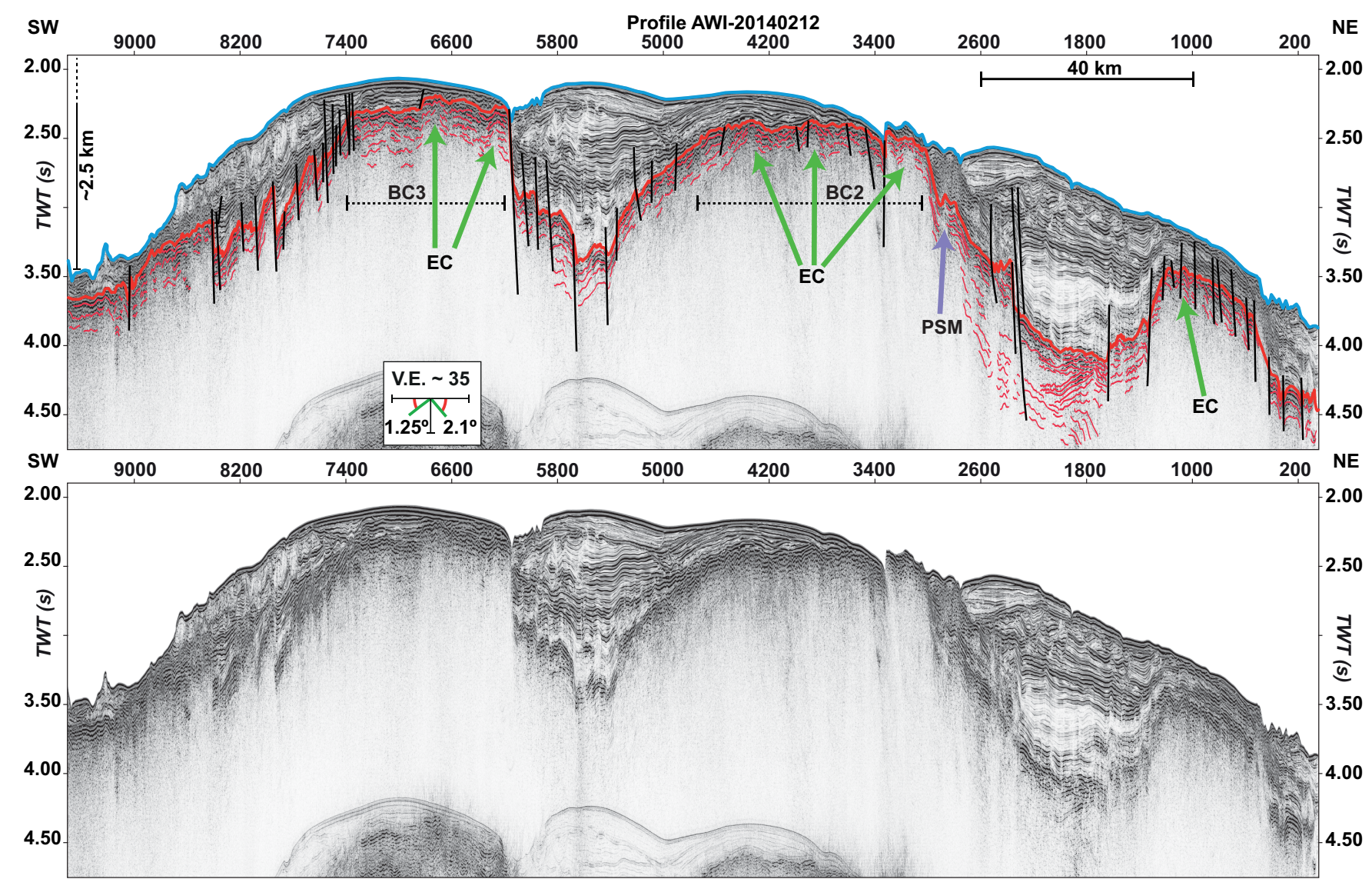

Figure 4. MCS profile AWI-20140212 crossing the central Mozambique Ridge in an NE-SW direction. Line and arrow colours as in Fig. 3 . BC2 $=$ Basement complex 2, BC3 = Basement complex 3. For slope angles and vertical exaggeration, refer to the legend. Location of profile is shown in Fig. 1.

resemble structures identified at the Manihiki Plateau, Shatsky Rise, and the Agulhas Plateau (Uenzelmann-Neben et al. 1999; Sager et al. 2013b; Pietsch \& Uenzelmann-Neben 2015), which have been interpreted as extrusion centres (ECs). Sedimentary deposits onlap the ECs indicating pre-sedimentary magmatism (e.g. Fig. 3 CDPs 3400-4200).

We observe a second type of magmatic structures characterized by a pull up of sedimentary layers suggesting a predominantly post-sedimentary development (Fig. 2 CDPs 9300-9900) here called post-sedimentary magmatic (PSM) structures. All PSM structures cause deformation up to seismic unit $\mathrm{S} 2 \mathrm{~b}$, even though not all of them pierce into the mid-Miocene to Holocene deposits. This is due to considerable differences in height from less than $100 \mathrm{~m}$ to more than $1200 \mathrm{~m}$ (using an averaged seismic velocity of $1500 \mathrm{~m} \mathrm{~s}^{-1}$ ). The lateral extent of the conical to cylicdrical PSM structures usually ranges from 1 to $4 \mathrm{~km}$ (e.g. Fig. 6 CDPs 1600 1700) thus much smaller than the observed ECs. The structures are mainly concentrated on the flanks of the segments, whereas only a few are observed adjacent to ECs (Fig. 5d).

\subsection{Faults}

We observe numerous breaks in lateral continuity of seismic units within the study area, some of them with small offsets of $<20-80 \mathrm{~ms}$ TWT only affecting basement and the intrabasement reflections (e.g. Fig. 4 CDP 3900, Fig. 6 CDP 3950 and Fig. 8 CDP 3500). The majority of the vertical offsets affect basement and seismic unit $\mathrm{S} 1$ (offsets up to 180 ms TWT; e.g. Fig. 4 CDP 6000, Fig. 6 CDP 2500 and Fig. 8 CDP 7200) with some causing deformation up to the seafloor with offsets greater than $1000 \mathrm{~ms}$ TWT (e.g. Fig. 3 CDP 4800, Fig. 6 CDP 2800 and Fig. 8 CDP 8050).

Vertical offsets or breaks in lateral continuities of seismic units, and kinking or bowing of seismic reflections are typical expressions of faults (Hajnal et al. 1996; Sager et al. 2013a). Depending on the age of the deformed strata the observed faults can be divided into three groups: (1) faults only affecting basement that probably developed during or shortly after emplacement of the basement, (2) faults dissecting basement and sedimentary deposits of seismic unit S1 with a minimum age of $\sim 100 \mathrm{Ma}$, and (3) faults deforming the whole sedimentary pile including basement and a maximum age of $\sim 15 \mathrm{Ma}$. The latter can be observed in multibeam data recorded at the swMozR during SO 232 as well and show a predominantly EW to WNW-ESE strike (Uenzelmann-Neben 2014).

\section{DISCUSSION}

\subsection{Intrabasement reflections and extrusion centres}

The seismic data show a large number of ECs randomly distributed across the three segments of the southern MozR (Fig. 5c). Defining characteristics of the convex upward shaped ECs are up to $15 \mathrm{~km}$ long parallel and subparallel sequences of intrabasement reflections diverging from their summits and the onlap of overlying sedimentary strata onto its surface, suggesting emplacement of the ECs before deposition of sediments took place. The intrabasement reflections vary in their reflection amplitude and continuity, and can 
(a)

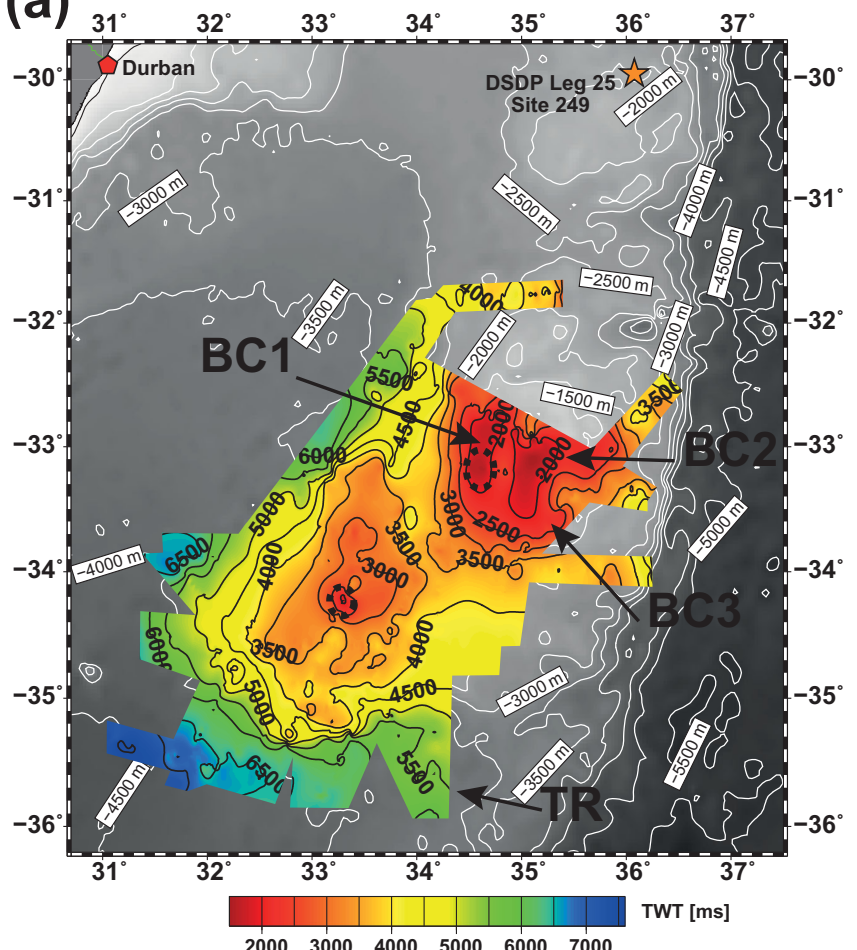

(c)

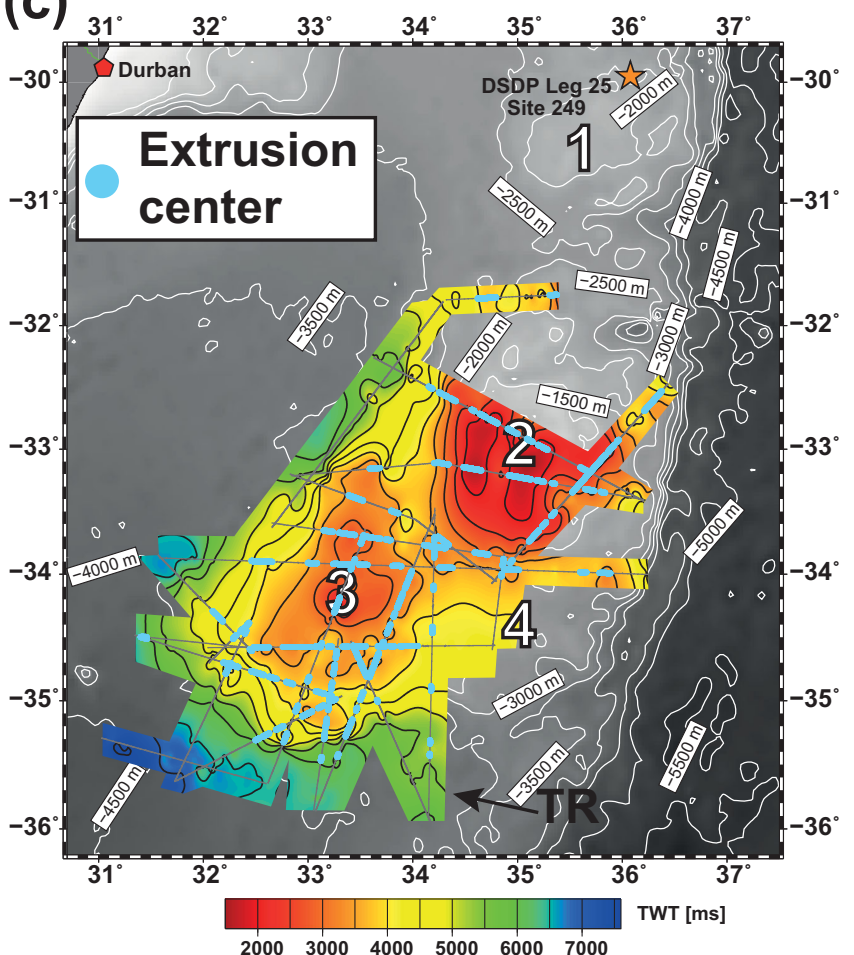

(b)

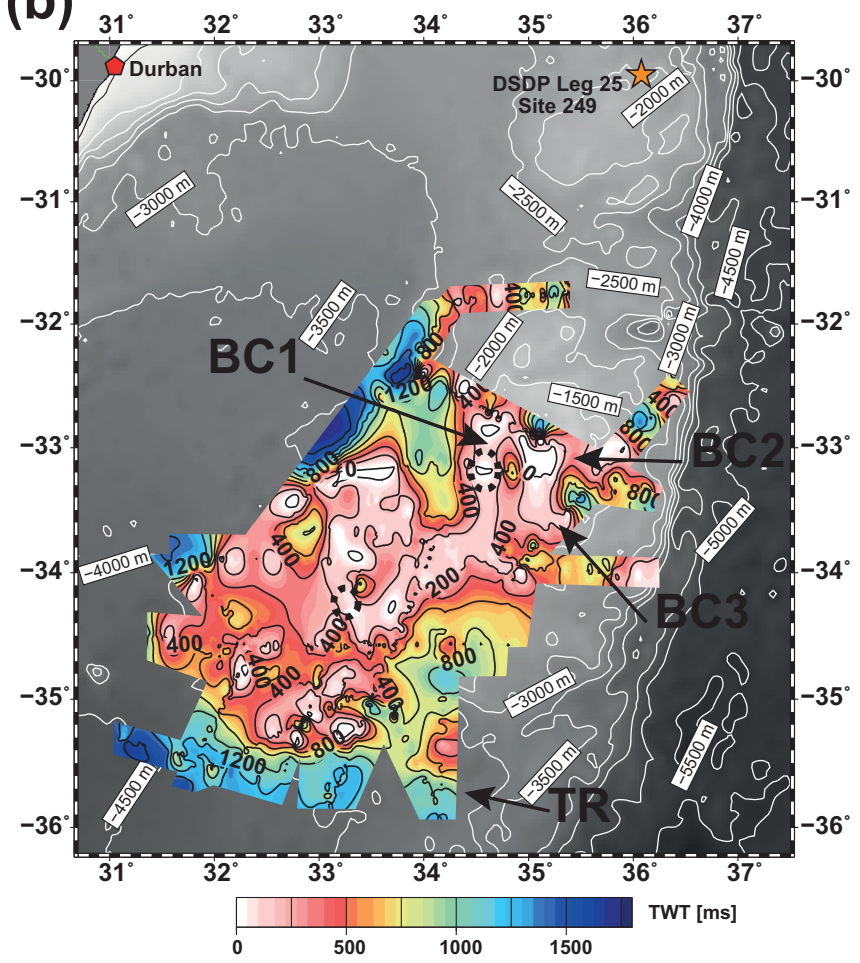

(d)

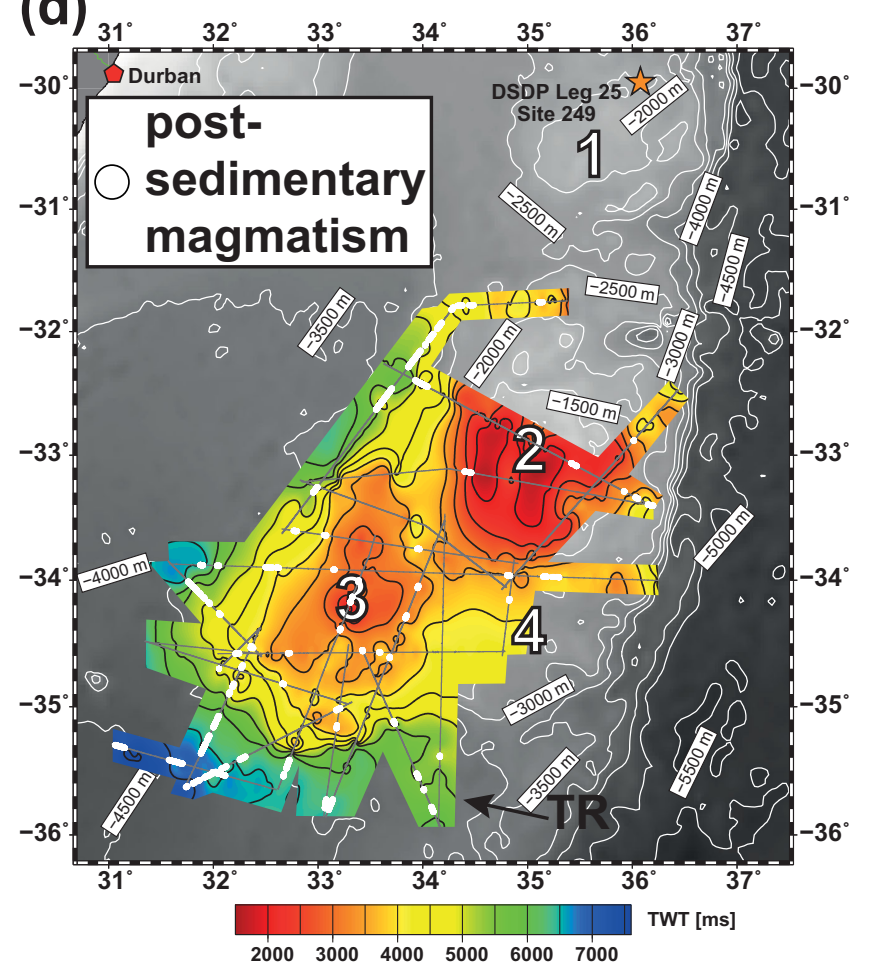

Figure 5. (a) Depth map (TWT) of top basement reflection (500 ms TWT contour lines in black) on top of greyscale bathymetric map (GEBCO_08; $500 \mathrm{~m}$ contour lines in white). Map shows location of DSDP Leg 25 Site 249 (star) and Durban (pentagon). BC1, BC2 and BC3 indicate the location of the basement complexes of the cMozR, the black dashed ellipses mark prominent basement highs, and TR stands for Transkei Rise. (b) Isopach map (TWT) of the sedimentary deposits in the study area (200 ms TWT contour lines in black). (c) Locations of extrusion centres (cyan dots) within the study area on top of the basement depth map (Fig. 5a). Location of MCS profiles is shown in thin black lines. White numbers depict the segments of the Mozambique Ridge: $1=$ northern Mozambique Ridge, 2 = central Mozambique Ridge, 3 = southwestern Mozambique Ridge, $4=$ southeastern Mozambique Ridge. (d) Map of the observed post-sedimentary magmatic features (white dots) plotted on top of the basement depth map (Fig. 5a). 


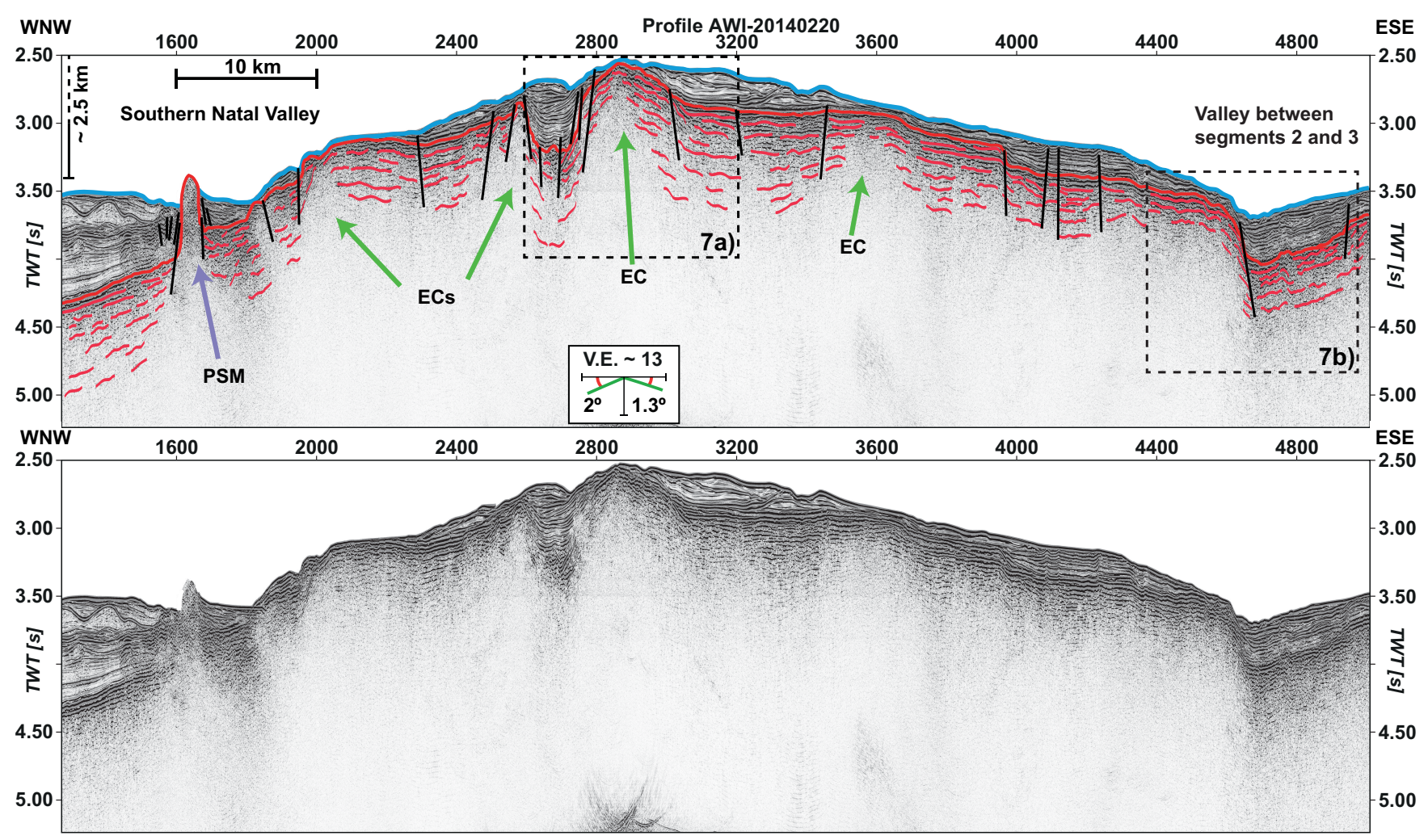

Figure 6. MCS profile AWI-20140220 crossing the southwestern Mozambique Ridge in a WNW-ESE direction. Line and arrow colours as in Fig. 3. For slope angles and vertical exaggeration, refer to the legend. The dashed frames indicate the locations of Figs 7(a) and (b). Location of profiles is shown in Fig. 1.

be identified as deep as $800 \mathrm{~ms}$ TWT below the top of basement (Figs 4 and 6). Similar observations of massive intrabasement reflections with varying geometries and amplitude characteristics have been reported for other locations around the world (e.g. Shatsky Rise, Agulhas Plateau, Kerguelen Plateau, Manihiki Plateau). Deep intrabasement reflections are characteristic for oceanic plateau eruptions (Sager et al. 2013b) and have been interpreted and in parts proven via drilling as lava flow sequences (Uenzelmann-Neben et al. 1999; Frey et al. 2000; Inoue et al. 2008; Parsiegla et al. 2008; Sager et al. 2013b; Pietsch \& Uenzelmann-Neben 2015). We hence interpret the observed intrabasement reflections at the MozR to represent lava flow sequences. This interpretation is backed by a rise in interval velocity from less than $2600 \mathrm{~m} \mathrm{~s}^{-1}$ within seismic units S1 and S2 to values of 3500 to $5000 \mathrm{~m} \mathrm{~s}^{-1}$ below the top of basement derived from velocity analyses of CDP gathers and the $P$-wave velocity-depth distribution model for the swMozR by Gohl et al. (2011).

The lava flow sequences observed in the seismic reflection data form successions of at least $1.4-1.7 \mathrm{~km}$ thickness converting the observed thicknesses in ms TWT into $\mathrm{m}$ using a velocity of $4.25 \mathrm{~km} \mathrm{~s}^{-1}$. The lava flow sequences represent only a small proportion of up to $22 \mathrm{~km}$ thick crust proposed to be built up by large volumes of mantle-derived magma (Gohl et al. 2011). This type of crust implies that either eruptive phases were long lasting or eruption rates were high. The postulated short time frame of only $\sim 13$ Myr during which emplacement of the southern MozR took place (König \& Jokat 2010) supports high eruption rates as the primary cause for the thick lava flow deposits. According to Coffin \& Eldholm (1994), Self et al. (2008) and Sager et al. (2013b) high eruption rates are typical for LIPs and the reason for their distinctive low slopes and thick lava sequences. We therefore propose that the observed low slopes and thick successions of lava sequences (e.g. Fig. 6) were caused by high eruption rates during emplacement of the southern MozR and thus favour a LIP origin of the MozR.

The geometry of the lava flow sequences is highly variable (e.g. dip angles and dip directions; Fig. 4 CDPs 1800-2200). The large number of ECs from which the intrabasement reflections emerge (e.g. Fig. 6 CDPs 2600-3200), and the observation of parallel and sub-parallel stratified sequences of intrabasement reflections, which overlap and onlap each other (e.g. Fig. 4 CDPs 1400-2200), points towards several eruptive phases during emplacement. LIPs are proposed to be constructed of eruptions from multiple locations (Jerram \& Widdowson 2005; Bryan et al. 2010). The observation of onlaps (Figs $7 \mathrm{~b}$ and c) of lava flow sequences emplaced at the cMozR onto lava flow sequences emerged from the swMozR are interpreted as evidence for an asynchronous emplacement of both segments: while magmatic output ceased at the swMozR, lava flow sequences were still being emplaced at the cMozR. Strong magnetic anomalies associated with the boundaries of the individual segments interpreted as evidence for formation of the segments at different ages (König \& Jokat 2010), which agrees well with our observations. We therefore suggest that the thick pile of lava flow sequences forming the southern MozR were emplaced during several eruptions via the randomly distributed ECs and favour sequential development of the southern MozR with the youngest segment located in the southeast.

\subsection{Post-sedimentary magmatism at the Mozambique Ridge}

Magmatic structures of proposed post-sedimentary magmatic (PSM) origin (deformation of above lying sedimentary sequences 


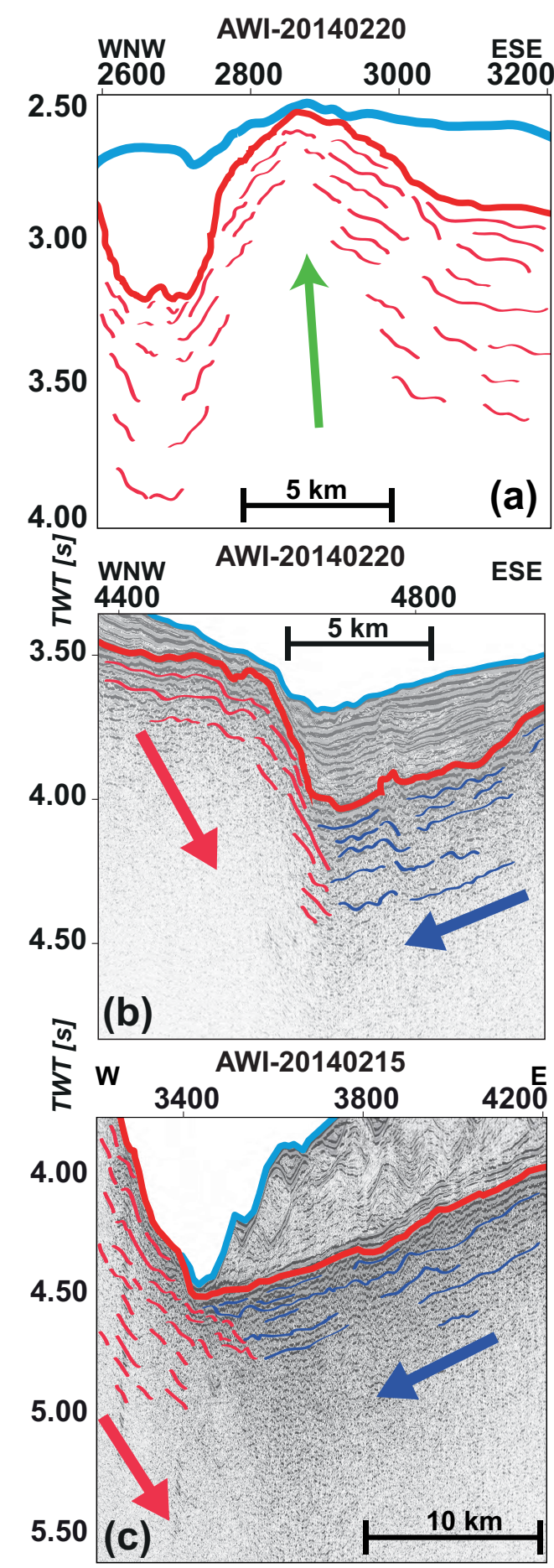

Figure 7. (a) Extrusion centre with lava flow sequences emerging and dipping away from it. Line colours as in Fig. 3. (b, c) Figures showing the area of the valley between the southwestern and central Mozambique Ridge. Line colours as in Fig. 3, except thin red lines = intrabasement reflections emerging from the southwestern Mozambique Ridge, thin blue lines = intrabasement reflections emerging from the central Mozambique Ridge. The arrows (red and blue) show the observed flow direction of the respective intrabasement reflections. with a pull-up at the structure's flanks, e.g. Fig. 3 CDPs 1300-1400, in places piercing of the seafloor, e.g. Fig. 6 CDPs 1600-1700) can be identified on the MozR. With their small diameters and steep flanks the PSM structures resemble piercement structures as described for the Kerguelen Plateau and interpreted as subvolcanic intrusives by Ramsay et al. (1986). Some of the PSM structures seem to coincide with the faults that deform a large proportion of the up to 15 Myr old seismic unit S2b (e.g. Fig. 6 CDPs 1600-1700).

The majority of PSM features are concentrated within the transition zone of the segments to the surrounding basins (e.g. Figs $5 \mathrm{~d}$ and 3 CDPs 9300-9900) with a distinct increase in abundance of PSM structures in the southwestern and northwestern part of the study area (Fig. 5d). All observed PSM structures led to deformation of parts of the overlying seismic unit S2b. This points to the onset of PSM activity after deposition of seismic unit S2b had already begun, thus after $15 \mathrm{Ma}$. This age corresponds to the probable onset of faulting associated with the breaks in lateral continuity, which in places affect seismic unit S2b up to seafloor (e.g. Fig. 3 CDP 200). Faulting of the mid-Neogene to Quaternary strata might thus be an ongoing process.

According to Chorowicz (2005), neotectonic and Neogene magmatic activity in East Africa are interconnected and a consequence of the East African Rift System. The rift valleys of the East African Rift System (EARS) form two main lines, the Eastern and Western rift branches, which have shown a general southward propagation since initiation of the EARS (inset in Fig. 1; Ebinger et al. 1989; Kampunzu et al. 1998; Calais et al. 2006). Parts of the onshore Western rift branch terminate in the Mozambique Coastal Plains north of the study area (Stamps et al. 2008; Saria et al. 2014; Wiles et al. 2014). Magmatic activity in the western branch commenced $\sim 11 \mathrm{Ma}$ in the north and $\sim 8.6 \mathrm{Ma}$ in the south, thus following the general southward trend of rift propagation of the EARS (Kampunzu et al. 1998; Macgregor 2015).

Several authors suggested a seaward propagation of the Eastern branch of the EARS but there is a strong dissent about whether there exists an offshore extension of the Western branch (Mougenot et al. 1986; Hartnady et al. 1992; Kampunzu et al. 1998; Stamps et al. 2008; Saria et al. 2014; Wiles et al. 2014; Franke et al. 2015; Klimke et al. 2015). Hartnady et al. (1992) and Ben-Avraham et al. (1995) related neotectonic activity in the vicinity of the MozR to a propagation of the Western branch of the EARS into the Natal Valley. Tikku et al. (2002) supported a seaward extension of the Western branch of the EARS into the northeastern Natal Valley on the basis of free-air gravity lows interpreted as neotectonic faults. A seaward propagation was recently revisited by Wiles et al. (2014) as a probable cause for up to $31 \mathrm{~km}$ long and $18 \mathrm{~km}$ wide seafloor mounds observed northwest of the MozR. Other authors proposed that the western boundary of the Lwandle microplate traces along the eastern border of the MozR (Stamps et al. 2008; Saria et al. 2014; Stamps et al. 2014), thus presenting another probable connection of neotectonic activity to a southward propagation of the EARS in the vicinity of the MozR.

We suggest that both PSM structures and neotectonic activity creating the faults deforming seismic unit $\mathrm{S} 2 \mathrm{~b}$ are caused by seaward propagation of the Western branch of the EARS in Late Miocene times. This is based on the age of the deformed seismic unit S2b $(<15 \mathrm{Ma})$ and its chronological correlation to the onset of rifting in the Western branch of the EARS (Nyblade \& Brazier 2002). If we follow the proposed southward decrease in age of volcanism at the onshore Western branch and its onset in the south $\sim 8.6 \mathrm{Ma}$ (Kampunzu et al. 1998; Macgregor 2015), it is likely that postsedimentary magmatism at the MozR commenced after 8.6 Ma. 


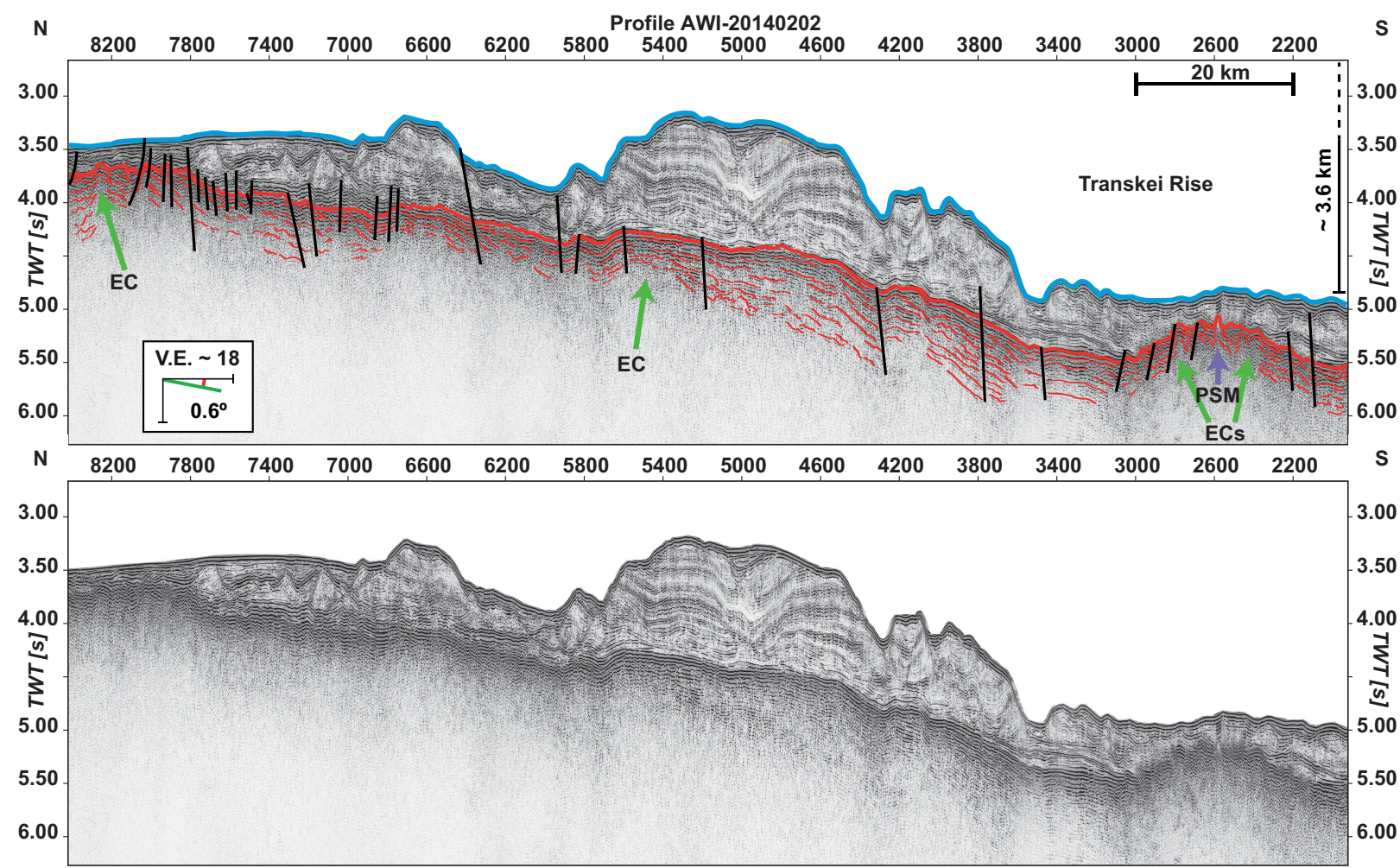

Figure 8. N-S striking MCS profile AWI-20140202 across the southeastern Mozambique Ridge. Line and arrow colours as in Fig. 3. For slope angles and vertical exaggeration, refer to the legend. Location of profile is shown in Fig. 1.

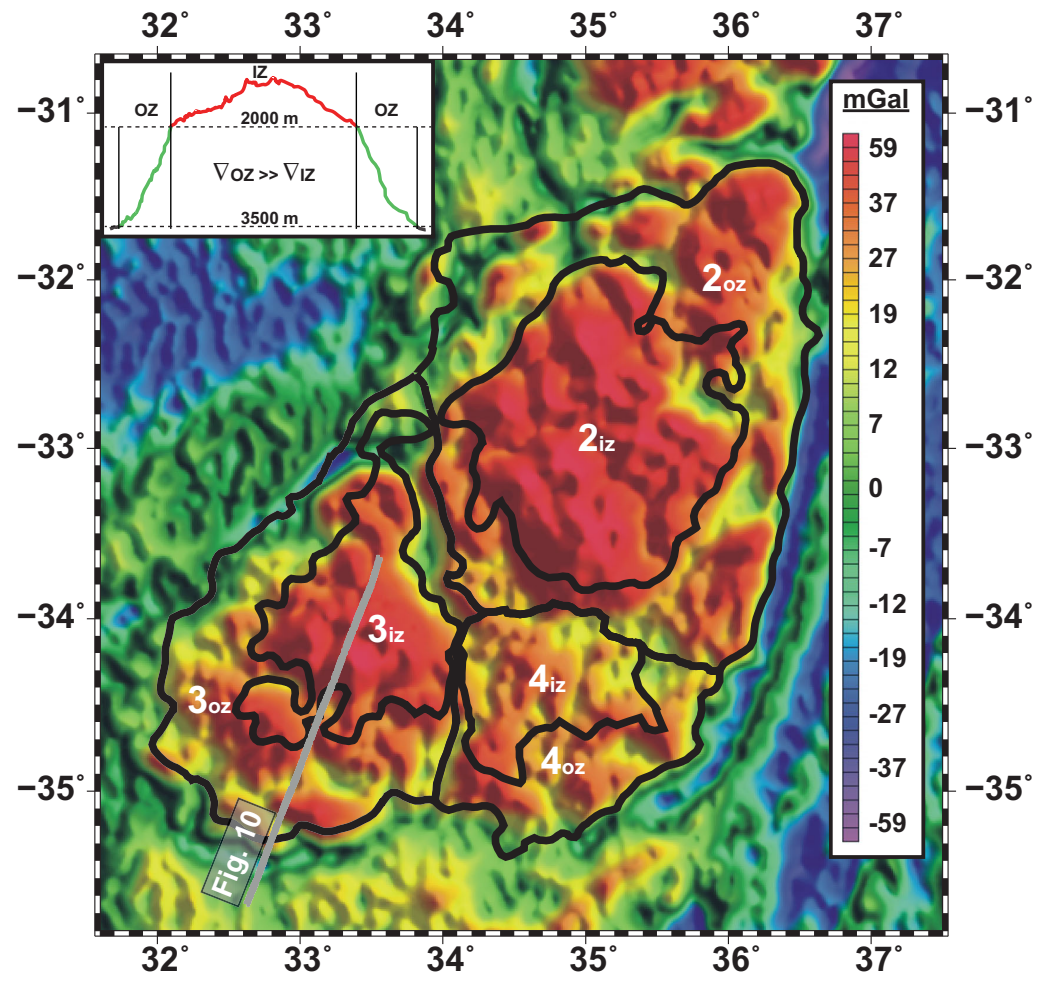

Figure 9. Free-air gravity anomaly map (after Sandwell \& Smith 2009) with subdivision of the individual plateaus of the Mozambique Ridge into an inner (iz) and outer zone (oz). The inner zones were constructed within the closed $2000 \mathrm{~m}$ depth contour at the central Mozambique Ridge (2iz), the closed $2500 \mathrm{~m}$ depth contour at the southwestern Mozambique Ridge (3iz) and the closed $2750 \mathrm{~m}$ depth contour at the southeastern Mozambique Ridge (4iz). The outer zones $(2 \mathrm{oz} / 3 \mathrm{oz} / 4 \mathrm{oz})$ were constructed between the outlines of the respective inner zones and the $3500 \mathrm{~m}$ isoline. The grey line illustrates the location of the $P$-wave velocity depth model of the swMozR by Gohl et al. (2011) shown in Fig. 10. The insert in the upper left corner shows the basis for differentiation between iz and oz using the example of the central Mozambique Ridge. $\nabla=$ gradient of basement depth. 
The observed piercing of the sedimentary deposits up to seafloor supports this.

We speculate that the over-thickened oceanic crust of the MozR (Gohl et al. 2011) acted as a 'barrier' for a continuation of southward propagation of the EARS thus leading to a concentration of PSM structures at the flanks and margins of the LIP. Several authors proposed that development of the Eastern and Western branches of the EARS are controlled by stress concentrations from rheological contrasts (Petit \& Ebinger 2000; Chorowicz 2005; Corti et al. 2007). The rigid crust of the MozR could represent such a rheological contrast and thus redirected the tectonic stress towards zones of structural weakness where it created pathways for igneous material. The thinner parts of the MozR as well as the transition into oceanic crust represents an ideal location for those areas of weakness.

\subsection{Magmatic volume of the southern Mozambique Ridge and implications for its emplacement history}

We have seen that the magmatic basement of the MozR is characterized by a large number of extrusions centres (EC). This in combination with thick lava flow sequences within the basement resemble observations from other LIPs (e.g. Pietsch \& Uenzelmann-Neben 2015) and are therefore interpreted as strong evidence for a LIP origin of the MozR. The predominantly basaltic composition of the 59 rock samples dredged during SO 232 and preliminary geochemical results in favour of a plume component in the source of MozR volcanism also support this interpretation (Uenzelmann-Neben 2014; Jacques et al. 2015). The presence of an up to $22 \mathrm{~km}$ thick overthickened equivalent of oceanic layer 3 (Gohl et al. 2011) and the suggested emplacement of the MozR within a relatively short time span of $\sim 18$ Myr (König \& Jokat 2010) add to our interpretation of the southern MozR as a LIP (Bryan \& Ernst 2008; Kerr 2014). The duration of magmatic activity as well as the volume of magmatic material emplaced are further important parameters, which will be studied in the following.

\subsubsection{Volume of magmatism at the southern Mozambique Ridge}

The excess crustal volume acts as an important measurement for quantifying the amount of magmatic material involved in a LIP formation. In order to calculate the volume of magmatism of the MozR parameters like the crustal thickness, the areal extent and the thickness of the surrounding oceanic crust are needed.

In order to calculate the total areal extent of the southern MozR and account for the crustal thinning of LIPs at their marginal areas we constructed an inner and an outer zone for each segment (Fig. 9). The outlines of the outer zones were assigned to the $3500 \mathrm{~m}$ bathymetric depth contour bordering the positive free-air gravity anomalies (Sandwell \& Smith 2009) associated with the magmatic basement of the MozR (Fig. 9). The outlines of the inner zones were constructed based on the observation of distinct variations in gradient $(\nabla)$ of basement depth at each segment. Whereas the outer zones display a high $\nabla$, the inner zones demonstrate only a low $\nabla$ (insert in Fig. 9). To construct closed inner zones in areas where no information about basement depth (and thus $\nabla$ ) is available, we linked the boundaries to their corresponding bathymetric depth contours. The inner zones of the cMozR, swMozR and seMozR were therefore constructed within the closed 2000, 2500 and $2750 \mathrm{~m}$ depth contour (Fig. 9).

We calculated an areal extent of $6.1 \times 10^{4} \mathrm{~km}^{2}$ for the inner zones and $8.4 \times 10^{4} \mathrm{~km}^{2}$ for the outer zones (Table 2). With a total area of $14.5 \times 10^{5} \mathrm{~km}^{2}$ the southern MozR surpasses the suggested

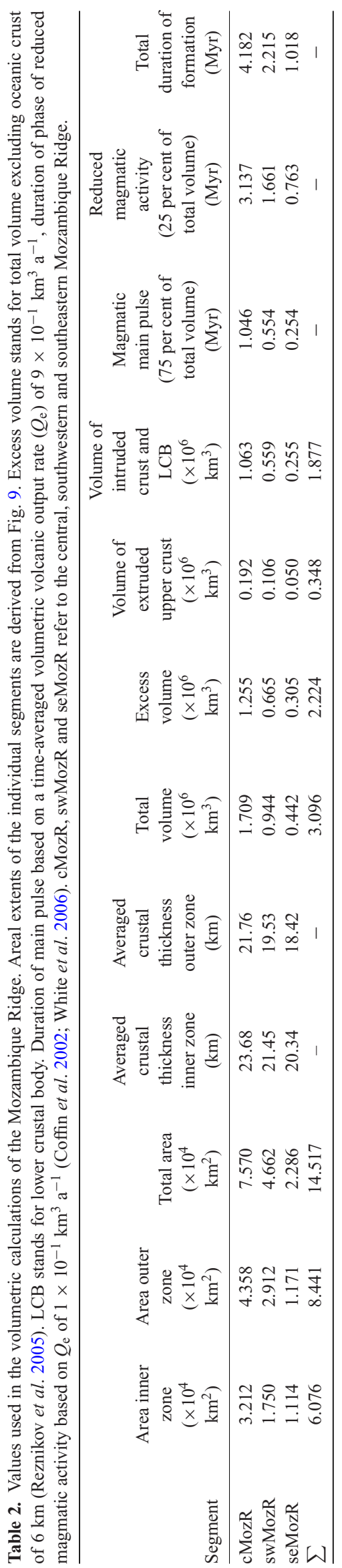




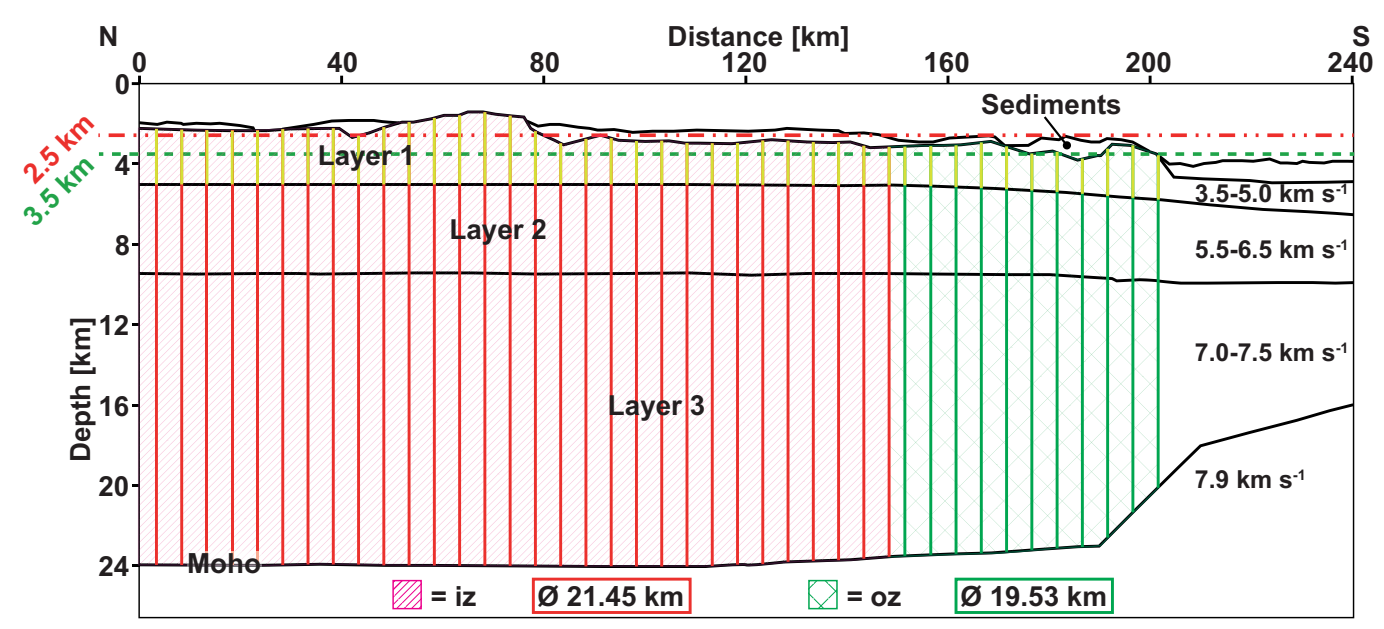

Figure 10. Simplified $P$-wave velocity depth model (after Gohl et al. 2011) that was used to determine the average thickness of the inner zone (iz; dashed in red) and the outer zone (oz; dashed in green) of the southwestern Mozambique Ridge. Horizontal dashed lines represent bathymetric depth contours ( $c f$. Fig. 9) used for construction of the inner zone ( $2500 \mathrm{~m}$; in red) and the outer zone ( $3500 \mathrm{~m}$; in green). Thickness was measured every $5 \mathrm{~km}$ within the zones. Yellow vertical lines were used to calculate the average thickness of the extruded upper crust (layer 1), red vertical lines (incl. associated yellow vertical lines) for calculating the average thickness of the inner zone, and green vertical lines (incl. associated yellow vertical lines) for calculating the average thickness of the outer zone. Velocities, layers, depth and profile distance based on Gohl et al. (2011). Refer to Section 5.3.1 for a detailed description.

threshold value for classifying LIPs of $1 \times 10^{5} \mathrm{~km}^{2}$ (Bryan \& Ernst 2008) by $\sim 45$ per cent (Fig. 11).

For the purpose of volume calculations the thickness of the swMozR was measured every $5 \mathrm{~km}$ within the inner and outer zones of the crustal velocity-depth model (Gohl et al. 2011) and averaged for the inner (hatched in red in Fig. 10) and outer zone (hatched in green in Fig. 10). This leads to an average thickness of $19.53 \mathrm{~km}$ for $3_{\mathrm{OZ}}$ and $21.45 \mathrm{~km}$ for $3_{\mathrm{IZ}}$, and a total crustal volume for the swMozR of $0.94 \times 10^{6} \mathrm{~km}^{3}$ (Table 2).

Only 1-D crustal thickness estimates of low resolution exist for the cMozR and the seMozR. Assuming Airy type isostatic equilibrium between the ridge and the adjacent oceanic basins (Hales \& Nation 1973; Recq \& Goslin 1981; Maia et al. 1990) we used the Airy-Heiskanen model to determine the crustal thickness of the cMozR and the seMozR. A $6 \mathrm{~km}$ thick oceanic crust (Reznikov et al. 2005) and an average basement depth of $6.3 \mathrm{~km}$ within the adjacent oceanic basin (Schlüter \& Uenzelmann-Neben 2007) were used as reference values together with a water density of $1000 \mathrm{~kg}$ $\mathrm{m}^{-3}$ and a mantle density of $3300 \mathrm{~kg} \mathrm{~m}^{-3}$. The density of the crust at the MozR was calculated to be $2944 \mathrm{~kg} \mathrm{~m}^{-3}$ based on the $P$-wave velocity depth model of the swMozR (Gohl et al. 2011) and the empirical density-velocity relation of Barton (1986).

This led to an average crustal thickness of 23.68 and $21.76 \mathrm{~km}$ for the inner and outer zones of the cMozR, and 20.34 and $18.42 \mathrm{~km}$ for the inner and outer zones of the seMozR, respectively (Table 2). The crustal volume of the cMozR is thus estimated to be $1.71 \times 10^{6}$ $\mathrm{km}^{3}$, and of the seMozR $0.44 \times 10^{6} \mathrm{~km}^{3}$ (Table 2). The sum of the crustal volumes of the three segments is $3.10 \times 10^{6} \mathrm{~km}^{3}$ including extrusive and subvolcanic (upper crustal) intrusive volumes, and middle and lower crustal components (Table 2). The results should only be considered as a tentative minimum estimate and do not account for the whole MozR due to the lack of data for the northern Segment 1.

Eldholm \& Coffin (2000) summarized that volumes of LIPs range from $0.7 \times 10^{6} \mathrm{~km}^{3}$ to $44.4 \times 10^{6} \mathrm{~km}^{3}$. Our results for the southern MozR thus fall into the lower range. Examples of areal extent and volumetric distribution of several LIPs including the southern MozR are shown in Fig. 11, with the southern MozR having a size and volume that equals $\sim 70$ per cent of the Agulhas Plateau. Comparison of the crustal volume to area ratio shows that the southern MozR has a $\sim 20: 1$ ratio, which is slightly higher than the ratios of the oceanic LIPs of Agulhas Plateau, Kerguelen Plateau and Manihiki Plateau (Fig. 11). Continental LIPs, for example, the Columbia River Continental Flood Basalt Province, show a significant lower crustal volume to area ratio than the oceanic LIPs and the southern MozR (Fig. 11). We interpret this similarity of crustal volume to area ratios of oceanic LIPs with those of the MozR as support for an oceanic LIP origin of the MozR.

Subtracting the volume of a $6 \mathrm{~km}$ thick layer of oceanic crust as observed for the adjacent basin (Reznikov et al. 2005) leads to a magmatic excess volume of the southern MozR of $2.22 \times 10^{6} \mathrm{~km}^{3}$. We distinguish between an intruded crust/lower crustal body and an extruded upper crust in our calculations. Following the method used by Parsiegla et al. (2008) we estimated the extruded upper crustal component by picking the thickness of layer 1 characterized by velocities between 3.5 and $5 \mathrm{~km} \mathrm{~s}^{-1}$ in the velocity-depth model of the swMozR (Gohl et al. 2011) every $5 \mathrm{~km}$ (yellow vertical lines in Fig. 10). The average thickness within the inner zone is $2.5 \mathrm{~km}$ and within the outer zone $2.1 \mathrm{~km}$. We calculated the ratio of extruded upper crust to total crustal thickness for the inner (11.87 per cent) and outer zone (10.73 per cent) of the swMozR. By applying these ratios to the crustal thicknesses of both other segments we were able to estimate the extruded upper crustal component at the cMozR $\left(2_{\mathrm{IZ}}=2.81 \mathrm{~km} ; 2_{\mathrm{OZ}}=2.33 \mathrm{~km}\right)$ and the seMozR $\left(4_{\mathrm{IZ}}=2.42 \mathrm{~km} ; 4_{\mathrm{OZ}}=1.98 \mathrm{~km}\right)$. Based on these estimates the amount of extruded material of the three segments is found to be $3.48 \times 10^{5} \mathrm{~km}^{3}$ (Table 2). The calculated volume of extruded material of the MozR exceeds the minimum specifications for a LIP of $1 \times 10^{5} \mathrm{~km}^{3}$ (Bryan \& Ernst 2008) by almost 250 per cent, supporting a LIP origin of the MozR as postulated by Gohl et al. (2011). The remaining excess volume of $1.88 \times 10^{6} \mathrm{~km}^{3}$ (Table 2) intruded into the oceanic crust and accounts for the strongly increased thickness of the seismically homogeneous, lower crustal units (Gohl et al. 2011).

Based on our results the southern MozR shows an intrusive to extrusive ratio (I:E) of $\sim 5: 1$. Following Bryan \& Ernst (2008) the 


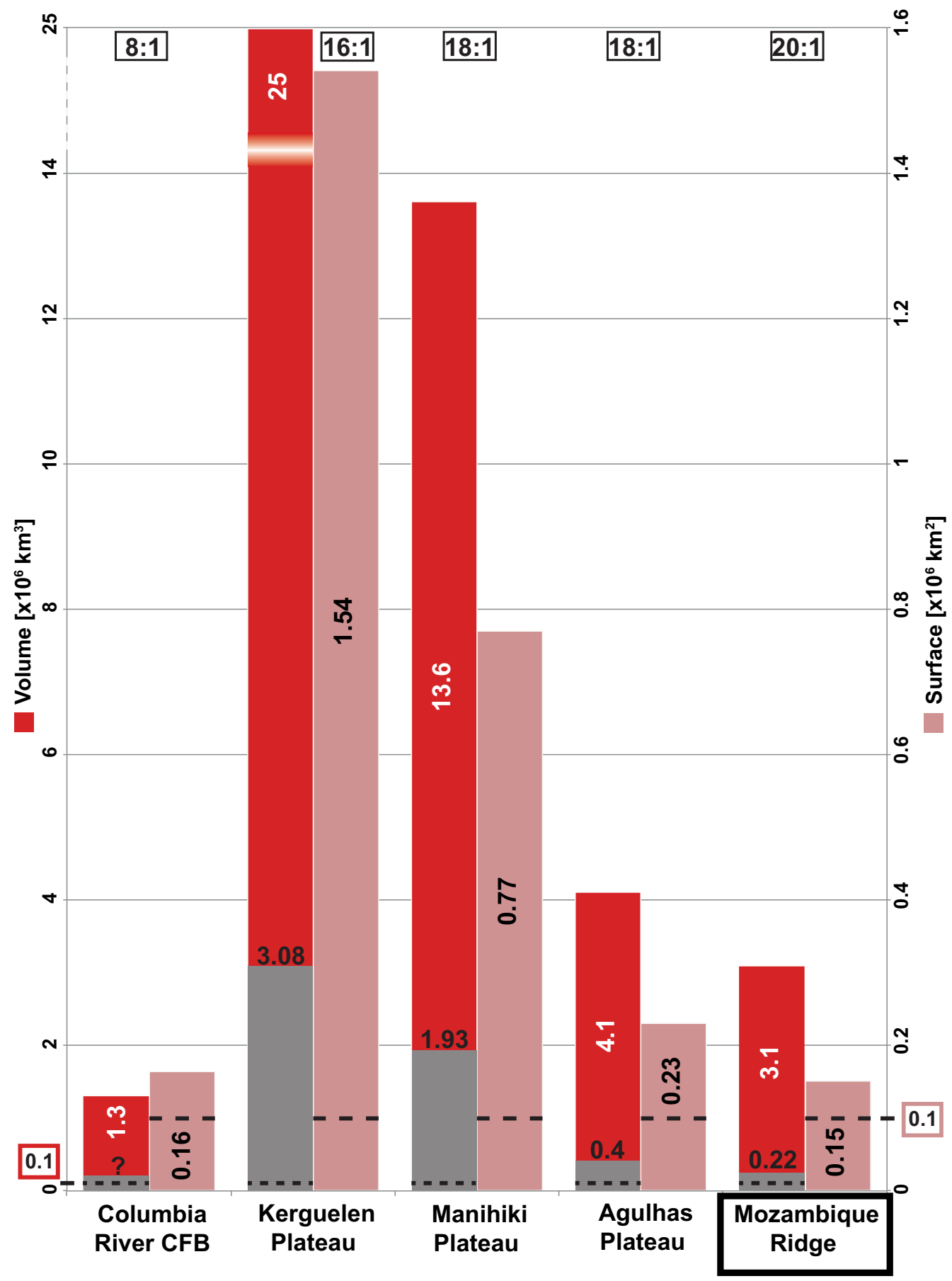

Figure 11. Graph illustrating the areal extent (light red bar) and crustal volume (dark red bar: extruded upper crust + intruded crust + lower crustal body; grey: extruded upper crust) of the southern Mozambique Ridge, selected oceanic plateau LIPs and the Columbia River Continental Flood Basalt Province (no data available for volume of extruded upper crust). Dashed lines represent threshold values for size $\left(0.1 \times 10^{6} \mathrm{~km}^{2}\right)$ and volume of extruded crust $(0.1 \times$ $10^{6} \mathrm{~km}^{3}$ ) of a LIP suggested by Bryan \& Ernst (2008). Proportions stated in the uppermost part of the graph yield ratios of total crustal volume to areal extent of each LIP. (Agulhas Plateau: Parsiegla et al. 2008; Columbia River CFB: Hooper 1988; Baksi 1989; Coffin \& Eldholm 1994; Kerguelen Plateau: Coffin \& Eldholm 1994; Frey et al. 2003; Manihiki Plateau: Coffin \& Eldholm 1994; Inoue et al. 2008).

volume of the intruded and lower crustal body of a LIP can be up to ten times larger than the associated extruded upper crust. Their statement rests on the findings of Crisp (1984) who examined a loosely constrained I:E ratio of 3:1 to $16: 1$ for mafic rock volumes worldwide. The results for the I:E ratio of the MozR show a high proportion of extruded upper crust, which bear witness to the highly eruptive nature of the MozR.

\subsubsection{Timing and duration of emplacement of the Mozambique Ridge}

White et al. (2006) calculated time-averaged volumetric volcanic output rates $\left(Q_{\mathrm{e}}\right)$ based on volcanic eruption data published from 1962 to 2005 , and proposed a $Q_{\mathrm{e}}$ of $9 \pm 2 \times 10^{-1} \mathrm{~km}^{3} \mathrm{a}^{-1}$ for flood basalt provinces and oceanic plateaus. But magma output rate is not constant over time. Coffin et al. (2002) observed that following the 


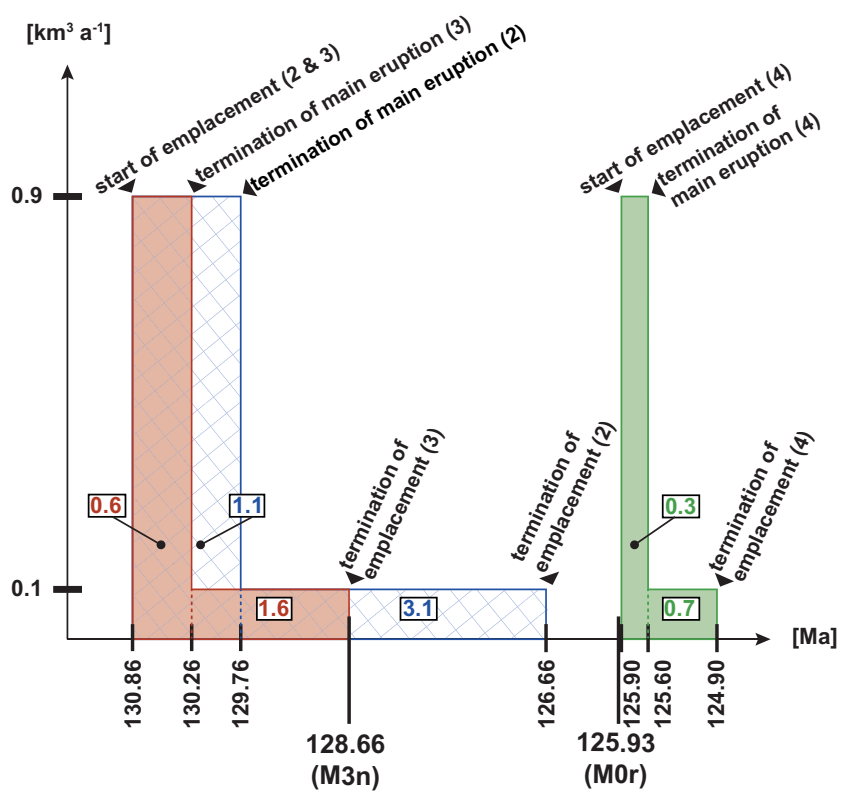

Figure 12. Illustration of duration of emplacement phases (numbers within white boxes) of the individual segments. Central Mozambique Ridge: blue bar with hatching, southwestern Mozambique Ridge: red bar, southeastern Mozambique Ridge: green bar. The onset and termination of each phase is marked on the $x$-axis (refer to Section 5.3.2 for explanation), whereas the $y$-axis indicates the used time-averaged volumetric volcanic output rates ( $Q_{\mathrm{e}}$; Coffin et al. 2002; White et al. 2006) the calculations are based on.

peak in magma production $\left(Q_{\mathrm{e}}=9 \times 10^{-1} \mathrm{~km}^{3} \mathrm{a}^{-1}\right)$ at the Southern Kerguelen Plateau magmatic output waned by nearly an order of magnitude to $\sim 0.1 \times 10^{-1} \mathrm{~km}^{3} \mathrm{a}^{-1}$. Karlstrom \& Richards (2011) suggested magmatic activity of LIPs on two distinct timescales: an intrusion-dominated regime with only minor eruptions lasting the total active lifetime of a LIP, and a distinctively shorter 'main stage' during which most of its volume is emplaced. The main pulse can be very brief (less than $1 \mathrm{Myr}$ ), but accounts for more than 75 per cent of the total volume of magmatic output (Camp et al. 2003; Courtillot \& Renne 2003; Bryan \& Ernst 2008). Karlstrom \& Richards (2011) proposed that terminations of main eruption phases are a probable result of shutoff of dike propagation from the deep crust. It was suggested that the transition from the main eruption phase to the phase of strongly decreased magmatic output happens abruptly (Coffin et al. 2002). Bryan et al. (2002) and Jerram \& Widdowson (2005) related the interval of reduced magmatic output to a waning and more protracted phase of volcanism where the volume of eruptions rapidly decreases and may become more widely distributed or focused when rifting occurs.

Adopting a presumed magmatic activity on two distinct timescales (e.g. Karlstrom \& Richards 2011) and following Coffin et al. (2002) and White et al. (2006) we apply a $Q_{\mathrm{e}}$ of $9 \times$ $10^{-1} \mathrm{~km}^{3} \mathrm{a}^{-1}$ for estimating the duration of the magmatic main pulse (75 per cent of the total volume), and a $Q_{\mathrm{e}}$ of $1 \times 10^{-1} \mathrm{~km}^{3}$ $\mathrm{a}^{-1}$ to calculate the duration of the phase of reduced magmatic activity (remaining 25 per cent of the total volume) (Fig. 12). Using our estimates of the magmatic volume of the southern MozR (Table 2) this results in the duration of the main pulse of $\sim 1.1 \mathrm{Myr}$ for the cMozR, $\sim 0.6 \mathrm{Myr}$ for the swMozR and $\sim 0.3 \mathrm{Myr}$ for the seMozR (Fig. 12 and Table 2). The length of the phase of reduced magmatic activity amounts to 23.1 Myr for the cMozR, $\sim 1.6$ Myr for the swMozR and $\sim 0.7$ Myr for the seMozR (Fig. 12 and Table 2).
Based on the analysis of magnetic anomalies König \& Jokat (2010) proposed a formation of the MozR between 140 and $120 \mathrm{Ma}$. We have updated their ages of magnetic anomalies using the age calibration of Ogg (2012). König \& Jokat (2010), distinguish four phases of formation: Segment 1 was formed between 140 and 135.32 Ma (prior to magnetic anomaly M11n, Fig. 13a), a simultaneous onset of formation of the cMozR and the swMozR with no clear specification for the commencement (sometime after 135.32 Ma, i.e. magnetic anomaly M11n) but a cessation of formation of the swMozR at $128.66 \mathrm{Ma}$ (magnetic anomaly M3n) while the cMozR continued to grow until $125.93 \mathrm{Ma}$ (magnetic anomaly M0r), and the seMozR formed between $125.93 \mathrm{Ma}$ (magnetic anomaly M0r) and $\sim 120 \mathrm{Ma}$.

Using our estimated durations for the main magmatic pulses and later emplacement periods in combination with König \& Jokat's (2010) reconstruction results in the tentative scenario for the development of the MozR shown in Fig. 13. Anomaly M3n forms a tie point in their model because the swMozR at that time had already been formed to its full extent while the cMozR continued to grow (Fig. 13c). Since König \& Jokat (2010) have no clear evidence for the onset of magma emplacement at the cMozR and the swMozR we use anomaly M3n (128.66 Ma) to calculate the onset of formation of the swMozR as $130.86 \mathrm{Ma}(128.66 \mathrm{Ma}+0.6 \mathrm{Myr}$ main pulse $+1.6 \mathrm{Myr}$ reduced magmatic phase) (Fig. 13b). Build-up of the cMozR then continued for another $2 \mathrm{Myr}$ with a cessation of magma production at $\sim 126.66 \mathrm{Ma}$ (Fig. 13d). That eruptive activity of the cMozR exceeded that of the swMozR is supported by the onlaps of intrabasement reflections originating from ECs of the cMozR onto intrabasement reflections emerging from the swMozR (Figs $7 b$ and c). Whether magma flux of the cMozR and the swMozR diminished abruptly or gradually is open to interpretation and cannot be determined based on the seismic data. The seMozR started to develop shortly after M0r with its main eruption phase beginning $\sim 125.90$ Ma probably while passing the Astrid Ridge. The main eruption phase of the seMozR lasted about 0.3 Myr (Fig. 13e). The final phase of intrusive processes and minor eruptions started at about $\sim 125.6 \mathrm{Ma}$ and lasted for $\sim 0.7 \mathrm{Myr}$ (Fig. 13f).

\section{CONCLUSIONS}

The analysis of the first high-resolution MCS reflection dataset covering the three southern segments of the MozR provided detailed information on its structure and development.

(1) Seismic stratigraphy identifies two sedimentary units and the basaltic basement showing deep reaching intrabasement reflections known from other study areas and classified as lava flow sequences typical for LIPs.

(2) Based on a comprehensive analysis of our data we can conclude that MozR can be classified as a LIP. Amongst others this classification is based on the presence of numerous extrusion centres, deep reaching lava flow sequences and size and crustal volume of the MozR.

(3) The MozR is constructed of four segments, and the three southern segments are a consequence of sequential development by excessive volcanic activity.

(4) We propose emplacement of the individual segments between 130.9-126.7 Ma (cMozR), 130.9-128.7 Ma (swMozR) and 125.9124.9 Ma (seMozR).

(5) Besides extrusion centres corresponding to the initial development of the segments post-sedimentary magmatic features are observed within the study area. We suggest that late stage 

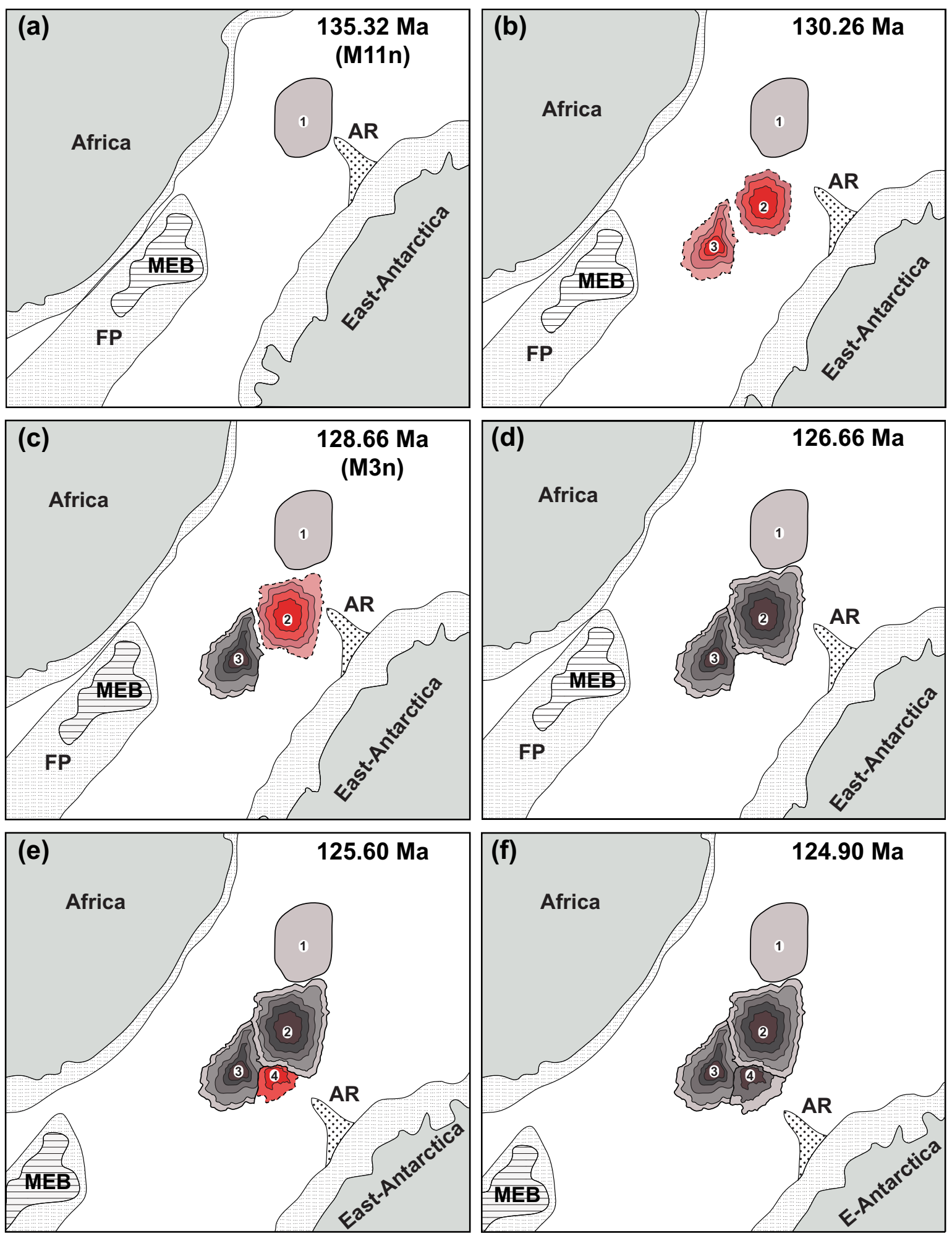

Figure 13. Schematic sketch of the proposed emplacement model for the southern Mozambique Ridge. The framework conditions of the model are based on the plate tectonic reconstruction by König \& Jokat (2010). Life spans of the individual segments are based on time-averaged volcanic output rates (Fig. 12; Coffin et al. 2002; White et al. 2006). Age calibration is based on Ogg (2012). 1 = northern Mozambique Ridge (nMozR), $2=$ central Mozambique Ridge $(\mathrm{cMozR}), 3$ = southwestern Mozambique Ridge (swMozR), $4=$ southeastern Mozambique Ridge (seMozR), AR = Astrid Ridge, FP = Falkland Plateau, $\mathrm{MEB}=$ Maurice Ewing Bank. (a) nMozR was formed prior to M11n between 140 and 135.32 Ma (König \& Jokat 2010). (b) Onset of magmatic activity at cMozR \& swMozR started $\sim 130.86$ Ma. Main eruption phases terminated $\sim 130.26$ Ma at swMozR and continued for another $\sim 0.5 \mathrm{Myr}$ at $\mathrm{cMozR}$. (c) Emplacement of swMozR was completed $\sim 128.66 \mathrm{Ma}$ (M3n) after a $\sim 1.6 \mathrm{Myr}$ lasting phase of intrusive processes and minor eruptions. (d) Phase of reduced magmatic activity at cMozR lasted $\sim 3.1$ Myr with formation of cMozR being completed $\sim 126.66$ Ma. (e) Emplacement of seMozR started shortly after M0r (125.93 Ma) about 125.90 Ma and main eruption phase terminated $\sim 125.60 \mathrm{Ma}$; (f) Phase of decreased magmatic output of seMozR lasted for $\sim 0.7 \mathrm{Ma}$, thus formation of the southern MozR was completed $124.90 \mathrm{Ma}$. 
magmatism corresponds to a seaward propagation of the Western branch East African Rift System in Late Miocene.

\section{ACKNOWLEDGEMENTS}

We want to express our gratitude to Captain Detlef Korte and his officers and crew of RV Sonne for their professional and enthusiastic engagement and service during the scientific program of this leg. The cruise leg SO 232 and the project SLIP were primarily funded by the German Federal Ministry of Education and Research (BMBF) under project number 03G0232A. Additional funding has been provided by the Alfred-Wegener-Institut. We thank M. Coffin, R. Reece and G. Laske (editor) for their detailed and helpful comments that improved our manuscript.

\section{REFERENCES}

Baksi, A.K., 1989. Reevaluation of the timing and duration of extrusion of the Imnaha, Picture Gorge, and Grande Ronde Basalts, Columbia River Basalt Group, Geol. Soc. Am. Spec. Pap., 239, 105-112.

Barton, P.J., 1986. The relationship between seismic velocity and density in the continental crust-a useful constraint?, Geophys. J. R. astr. Soc., 87, 195-208.

Ben-Avraham, Z., Hartnady, C.J.H. \& le Roex, A.P., 1995. Neotectonic activity on continental fragments in the Southwest Indian Ocean: Agulhas Plateau and Mozambique Ridge, J. geophys. Res., 100, 6199-6211.

Bryan, S.E. \& Ernst, R.E., 2008. Revised definition of Large Igneous Provinces (LIPs), Earth-Sci. Rev., 86, 175-202.

Bryan, S.E. \& Ferrari, L., 2013. Large igneous provinces and silicic large igneous provinces: progress in our understanding over the last 25 years, Bull. Geol. Soc. Am., doi:10.1130/B30820.1.

Bryan, S.E., Peate, I.U., Peate, D.W., Self, S., Jerram, D.A., Mawby, M.R., Marsh, J.S. \& Miller, J.A., 2010. The largest volcanic eruptions on Earth, Earth-Sci. Rev., 102, 207-229.

Bryan, S.E., Riley, T.R., Jerram, D.A., Stephens, C.J. \& Leat, P.T., 2002. Silicic volcanism: an undervalued component of large igneous provinces and volcanic rifted margins, Geol. Soc. Am. Spec. Pap., 362, 99-120.

Calais, E., Ebinger, C., Hartnady, C. \& Nocquet, J.M., 2006. Kinematics of the East African Rift from GPS and earthquake slip vector data, Geol. Soc. Lond. Spec. Publ., 259, 9-22.

Camp, V.E., Ross, M.E. \& Hanson, W.E., 2003. Genesis of flood basalts and Basin and Range volcanic rocks from Steens Mountain to the Malheur River Gorge, Oregon, Bull. Geol. Soc. Am., 115, 105-128.

Campbell, I.H., 2007. Testing the plume theory, Chem. Geol., 241, 153-176.

Chetty, P. \& Green, R.W.E., 1977. Seismic refraction observations in the Transkei Basin and adjacent areas, Mar. Geophys. Res., 3, 197-208.

Chorowicz, J., 2005. The East African rift system, J. Afr. Earth Sci., 43, 379-410.

Coffin, M.F. \& Eldholm, O., 1991. Large Igneous Provinces: JOI/USSAC Workshop Report, 79 pp., University of Texas at Austin Institute for Geophysics (Technical Report 114).

Coffin, M.F. \& Eldholm, O., 1994. Large igneous provinces: crustal structure, dimensions, and external consequences, Rev. Geophys., 32, 1-36.

Coffin, M.F., Pringle, M.S., Duncan, R.A., Gladczenko, T.P., Storey, M., Müller, R.D. \& Gahagan, L.A., 2002. Kerguelen Hotspot Magma Output since $130 \mathrm{Ma}$, J. Petrol., 43, 1121-1137.

Corti, G., van Wijk, J., Cloetingh, S. \& Morley, C.K., 2007. Tectonic inheritance and continental rift architecture: numerical and analogue models of the East African Rift system, Tectonics, 26, Tc6006, doi: $10.1029 / 2006 \mathrm{TC} 002086$.

Courtillot, V.E. \& Renne, P.R., 2003. On the ages of flood basalt events, C.R. Geosci., 335, 113-140.

Crisp, J.A., 1984. Rates of magma emplacement and volcanic output, $J$. Volcanol. Geotherm. Res., 20,177-211.

Cross, T.A. \& Lessenger, M.A., 1988. Seismic stratigraphy, Annu. Rev. Earth Planet. Sci., 16, 319-354.
Doucouré, C.M. \& Bergh, H.W., 1992. Continental origin of the Mozambique Plateau: a gravity data analysis, J. Afr. Earth Sci. (Middle East), 15, 311-319.

Ebinger, C.J., Deino, A.L., Drake, R.E. \& Tesha, A.L., 1989. Chronology of volcanism and rift basin propagation: Rungwe Volcanic Province, East Africa, J. geophys. Res., 94, 15 785-15803.

Eldholm, O. \& Coffin, M.F., 2000. Large Igneous Provinces and Plate Tectonics, in The History and Dynamics of Global Plate Motions, pp. 309326, eds Richards, M.A., Gordon, R.G. \& Van Der Hilst, R.D., American Geophysical Union.

Erlank, A.J. \& Reid, D.L., 1974. Geochemistry, mineralogy, and petrology of basalt, Leg 25, Deep Sea Drilling Project, in Initial Reports of the Deep Sea Drilling Project, eds Simpson, E.S.W. et al., doi:10.2973/dsdp.proc.25.122.1974.

Franke, D. et al., 2015. The offshore East African Rift System: structural framework at the toe of a juvenile rift, Tectonics, 34, 2086-2104.

Frey, F.A., Coffin, M.F., Wallace, P.J. \& Weis, D., 2003. Leg 183 synthesis: Kerguelen Plateau-Broken Ridge - a large Igneous Province, in Proceedings of the Ocean Drilling Program, Scientific Results, eds Frey, F.A., Coffin, M.F., Wallace, P.J. \& Quilty, P.G., Texas A\&M University Ocean Drilling Program.

Frey, F.A. et al., 2000. Origin and evolution of a submarine large igneous province: the Kerguelen Plateau and Broken Ridge, southern Indian Ocean, Earth planet. Sci. Lett., 176, 73-89.

Gohl, K. \& Uenzelmann-Neben, G., 2001. The crustal role of the Agulhas Plateau, southwest Indian Ocean: evidence from seismic profiling, Geophys. J. Int., 144, 632-646.

Gohl, K., Uenzelmann-Neben, G. \& Grobys, N., 2011. Growth and dispersal of a Southeast African large Igneous Province, S. Afr. J. Geol., 114, 379386.

Hajnal, Z., Lucas, S., White, D., Lewry, J., Bezdan, S., Stauffer, M.R. \& Thomas, M.D., 1996. Seismic reflection images of high-angle faults and linked detachments in the Trans-Hudson Orogen, Tectonics, 15, 427-439.

Hales, A.L. \& Nation, J.B., 1973. A seismic refraction study in the southern Indian Ocean, Bull. Seism. Soc. Am., 63, 1951-1966.

Hartnady, C.J.H., Ben-Avraham, Z. \& Rogers, J., 1992. Deep-ocean basins and submarine rises off the continental-margin of South-eastern Africa: new geological research, S. Afr. J. Sci., 88, 534-539.

Hooper, P.R., 1988. The Columbia River Basalt, in Continental Flood Basalts, pp. 1-33, ed. Macdougall, J.D., Springer.

Inoue, H., Coffin, M.F., Nakamura, Y., Mochizuki, K. \& Kroenke, L.W., 2008. Intrabasement reflections of the Ontong Java Plateau: implications for plateau construction, Geochem. Geophys. Geosyst., 9, Q04014, doi:10.1029/2007GC001780.

Jacques, G., Werner, R., Hauff, F., Hoernle, K. \& Uenzelmann-Neben, G., 2015. Preliminary geochemical results from the Mozambique Ridge, SW Indian Ocean, in AGU Annual Convention 2015, San Francisco, CA.

Jerram, D.A. \& Widdowson, M., 2005. The anatomy of continental flood basalt provinces: geological constraints on the processes and products of flood volcanism, Lithos, 79, 385-405.

Kampunzu, A.B., Bonhomme, M.G. \& Kanika, M., 1998. Geochronology of volcanic rocks and evolution of the Cenozoic Western Branch of the East African Rift System, J. Afr. Earth. Sci., 26, 441-461.

Karlstrom, L. \& Richards, M., 2011. On the evolution of large ultramafic magma chambers and timescales for flood basalt eruptions, J. geophys. Res., 116, B08216, doi:10.1029/2010JB008159.

Kerr, A.C., 2014. Oceanic plateaus, in Treatise on Geochemistry, 2nd edn, pp. 631-667, eds Holland, H. \& Turekian, K., Elsevier.

Klimke, J., Franke, D., Gaedicke, C., Schreckenberger, B., Schnabel, M., Stollhofen, H., Rose, J. \& Chaheire, M., 2015. How to identify oceanic crust - evidence for a complex break-up in the Mozambique Channel, off East Africa, Tectonophysics, doi:10.1016/j.tecto.2015.10.012.

König, M. \& Jokat, W., 2010. Advanced insights into magmatism and volcanism of the Mozambique Ridge and Mozambique Basin in the view of new potential field data, Geophys. J. Int., 180, 158-180.

Leclaire, L., 1974. Late Cretaceous and Cenozoic pelagic deposits; paleoenvironment and paleooceanography of the central western Indian Ocean, in 
Initial Report of the Deep Sea Drilling Project, Vol. 25, pp. 481-512, eds Simpson, E.S.W. et al., Government Printing Office, Washington, DC.

Lyakhovsky, V., Ben-Avraham, Z. \& Reznikov, M., 1994. Stress distribution over the Mozambique Ridge, Tectonophysics, 240, 21-27.

Macgregor, D., 2015. History of the development of the East African Rift System: a series of interpreted maps through time, J. Afr. Earth. Sci., 101, 232-252.

Maia, M., Diament, M. \& Recq, M., 1990. Isostatic response of the lithosphere beneath the Mozambique Ridge (SW Indian Ocean) and geodynamic implications, Geophys. J. Int., 100, 337-348.

Miura, S., Suyehiro, K., Shinohara, M., Takahashi, N., Araki, E. \& Taira, A., 2004. Seismological structure and implications of collision between the Ontong Java Plateau and Solomon Island Arc from ocean bottom seismometer-airgun data, Tectonophysics, 389, 191-220.

Mougenot, D., Gennesseaux, M., Hernandez, J., Lepvrier, C., Malod, J.A., Raillard, S., Vanney, J.R. \& Villeneuve, M., 1991. The Mozambique Ridge (Indian-Ocean) - a continental fragment shaped during the transform motion of American and Antarctic plates along East-Africa, C. R. Acad. Sci., Paris II, 312, 655-662.

Mougenot, D., Recq, M., Virlogeux, P. \& Lepvrier, C., 1986. Seaward extension of the East African Rift, Nature, 321, 599-603.

Nyblade, A.A. \& Brazier, R.A., 2002. Precambrian lithospheric controls on the development of the East African rift system, Geology, 30, 755-758.

Ogg, J.G., 2012. Geomagnetic polarity time scale, in The Geologic Time Scale 2012, pp. 85-113, Elsevier, doi:10.1016/B978-0-444-594259.00005-6.

Parsiegla, N., Gohl, K. \& Uenzelmann-Neben, G., 2008. The Agulhas plateau: structure and evolution of a large Igneous Province, Geophys. J. Int., 174, 336-350.

Petit, C. \& Ebinger, C., 2000. Flexure and mechanical behavior of cratonic lithosphere: gravity models of the East African and Baikal rifts, J. geophys. Res., 105, 19 151-19 162.

Pietsch, R. \& Uenzelmann-Neben, G., 2015. The Manihiki Plateau-a multistage volcanic emplacement history, Geochem. Geophys. Geosyst., 16, 2480-2498

Raillard, S., 1990. Les Marges de l'Afrique de l'est et les Zones de Fracture associées: Chaine Davie et Ride du Mozambique, Doctoral dissertation, Pierre and Marie Curie University, Paris.

Ramsay, D.C., Colwell, J.B., Coffin, M.F., Davies, H.L., Hill, P.J., Pigram, C.J. \& Stagg, H.M.J., 1986. New findings from the Kerguelen Plateau, Geology, 14, 589-593.

Recq, M. \& Goslin, J., 1981. Etude de l'equilibre isostatique dans le sudouest de l'ocean Indien a l'aide des resultats de refraction sismique, Mar. Geol., 41, M1-M10.

Reznikov, M., Ben-Avraham, Z., Hartnady, C. \& Niemi, T.M., 2005. Structure of the Transkei Basin and Natal Valley, Southwest Indian Ocean, from seismic reflection and potential field data, Tectonophysics, 397, 127-141.

Sager, W.W., Bull, J.M. \& Krishna, K.S., 2013a. Active faulting on the Ninetyeast Ridge and its relation to deformation of the Indo-Australian plate, J. geophys. Res., 118, 4648-4668.

Sager, W.W., Zhang, J., Korenaga, J., Sano, T., Koppers, A.A.P., Widdowson, M. \& Mahoney, J.J., 2013b. An immense shield volcano within the Shatsky Rise oceanic plateau, northwest Pacific Ocean, Nat. Geosci., 6, 976-981.

Sandwell, D.T. \& Smith, W.H.F., 2009. Global marine gravity from retracked Geosat and ERS-1 altimetry: Ridge segmentation versus spreading rate, J. geophys. Res., 114, doi:10.1029/2008JB006008.

Saria, E., Calais, E., Stamps, D.S., Delvaux, D. \& Hartnady, C.J.H., 2014. Present-day kinematics of the East African Rift, J. geophys. Res., 119, 3584-3600.

Saunders, A.D., 2005. Large Igneous Provinces: origin and environmental consequences, Elements, 1, 259-263.
Schlüter, P. \& Uenzelmann-Neben, G., 2007. Seismostratigraphic analysis of the Transkei Basin: a history of deep sea current controlled sedimentation, Mar. Geol., 240, 99-111.

Sclater, J.G., Grindlay, N.R., Madsen, J.A. \& Rommevaux-Jestin, C., 2005. Tectonic interpretation of the Andrew Bain transform fault: Southwest Indian Ocean, Geochem. Geophys. Geosyst., 6, Q09K10, doi:10.1029/2005GC000951.

Self, S., Jay, A.E., Widdowson, M. \& Keszthelyi, L.P., 2008. Correlation of the Deccan and Rajahmundry Trap lavas: are these the longest and largest lava flows on Earth?, J. Volcanol. Geotherm. Res., 172, 3-19.

Simpson, E.S.W. et al., 1974. The shipboard scientific party, in Initial Reports of the Deep Sea Drilling Project, pp. 287-346, eds Simpson, E.S.W. et al., Univ. Cape Town.

Stamps, D.S., Calais, E., Saria, E., Hartnady, C., Nocquet, J.-M., Ebinger, C.J. \& Fernandes, R.M., 2008. A kinematic model for the East African Rift, Geophys. Res. Lett., 35, L05304, doi:10.1029/2007GL032781.

Stamps, D.S., Flesch, L.M., Calais, E. \& Ghosh, A., 2014. Current kinematics and dynamics of Africa and the East African Rift System, J. geophys. Res., 119, 5161-5186.

Thompson, G., Bryan, W.B., Frey, F.A., Dickey, J.S. \& Davies, H., 1982. Petrology, geochemistry and original tectonic setting of basalts from the Mozambique Basin and Ridge (DSDP Sites 248, 249 and 250), and from the Southwest Indian Ridge (DSDP Site 251), Mar. Geol., 48, 175-195.

Tikku, A.A., Marks, K.M. \& Kovacs, L.C., 2002. An Early Cretaceous extinct spreading center in the northern Natal valley, Tectonophysics, 347, 87-108.

Tucholke, B.E., Houtz, R.E. \& Barrett, D.M., 1981. Continental crust beneath the Agulhas Plateau, southwest Indian Ocean, J. geophys. Res., 86, 3791-3806.

Uenzelmann-Neben, G., 2013. Volcanology: Magma giant, Nat. Geosci., 6, 902-903.

Uenzelmann-Neben, G., 2014. The Expedition of the Research Vessel "Sonne" to the Mozambique Ridge in 2014 (So 232), in Reports on Polar and Marine Research, pp. 207, ed. Uenzelmann-Neben, G., Alfred Wegener Institute for Polar and Marine Research.

Uenzelmann-Neben, G., Gohl, K., Ehrhardt, A. \& Seargent, M., 1999. Agulhas Plateau, SW Indian Ocean: new evidence for excessive volcanism, Geophys. Res. Lett., 26, 1941-1944.

Uenzelmann-Neben, G., Watkeys, M.K., Kretzinger, W., Frank, M. \& Heuer, L., 2011. Palaeoceanographic interpretation of a seismic profile from the southern Mozambique Ridge, southwestern Indian Ocean, S. Afr. J. Geol., 114, 449-458.

Vail, P.R., Mitchum, R.M., Todd, R.G., Widmier, J.M., Thompson, S., Sangree, J.B., Bubb, J.N. \& Hatlelid, W.G., 1977. Seismic stratigraphy and global changes of sea level, in Seismic Stratigraphy-Applications to Hydrocarbon Exploration, pp. 49-386, ed. Payton, C.E., American Association of Petroleum Geologists.

White, R.S. \& McKenzie, D., 1995. Mantle plumes and flood basalts, J. geophys. Res., 100, 17 543-17 585.

White, S.M., Crisp, J.A. \& Spera, F.J., 2006. Long-term volumetric eruption rates and magma budgets, Geochem. Geophys. Geosyst., 7, Q03010, doi:10.1029/2005GC001002.

Wignall, P.B., 2001. Large igneous provinces and mass extinctions, EarthSci. Rev., 53, 1-33.

Wiles, E., Green, A., Watkeys, M., Jokat, W. \& Krocker, R., 2014. Anomalous seafloor mounds in the northern Natal Valley, southwest Indian Ocean: implications for the East African rift system, Tectonophysics, 630, 300-312.

Yilmaz, Ö., 2001. Seismic Data Analysis, Society of Exploration Geophysicists. 